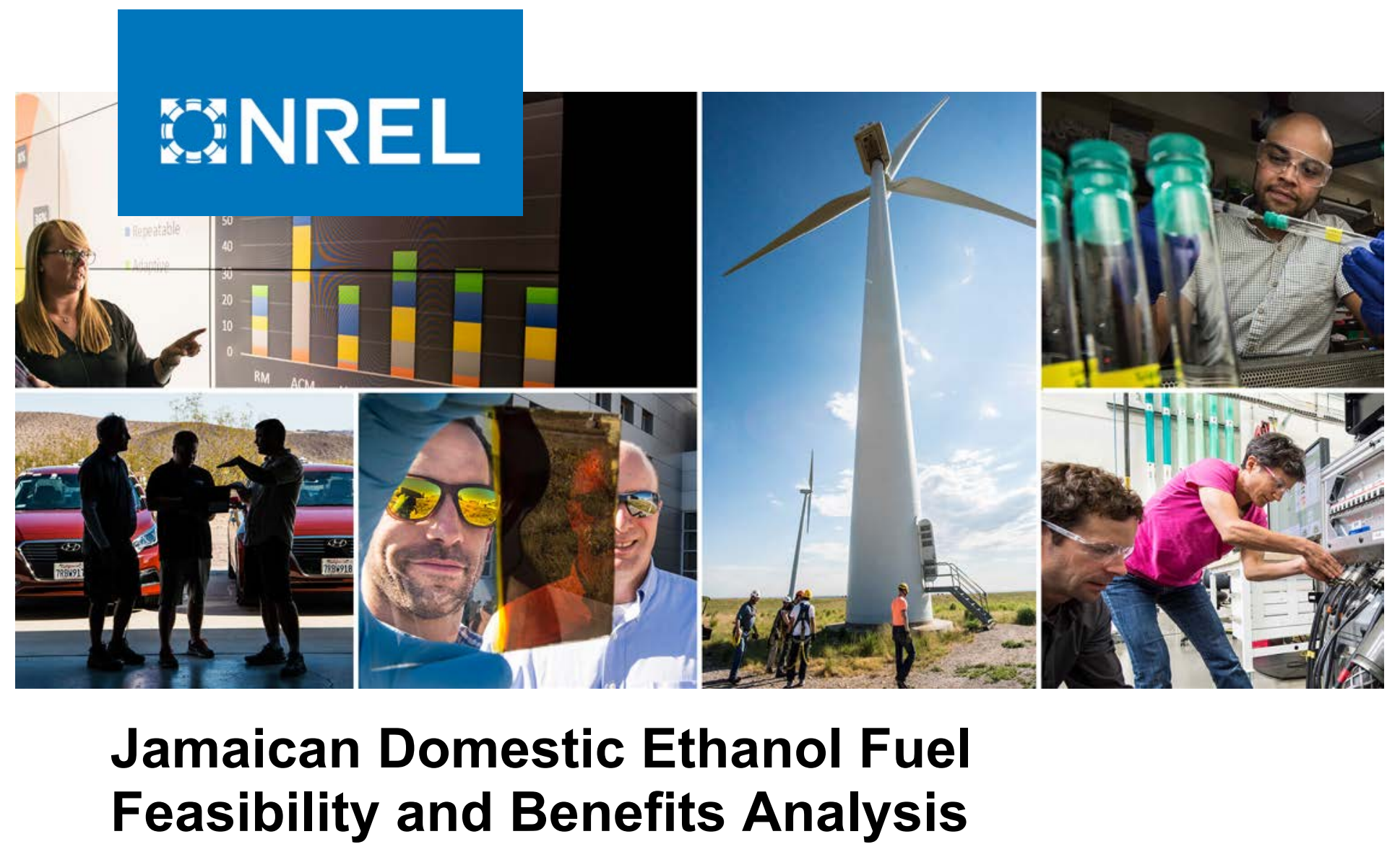

Caley Johnson, Anelia Milbrandt, Yimin Zhang, Rob Hardison, and Austen Sharpe

National Renewable Energy Laboratory

NREL is a national laboratory of the U.S. Department of Energy Office of Energy Efficiency \& Renewable Energy Operated by the Alliance for Sustainable Energy, LLC

This report is available at no cost from the National Renewable Energy Laboratory (NREL) at www.nrel.gov/publications.

Contract No. DE-AC36-08GO28308
Technical Report

NREL/TP-5400-76011

May 2020 


\title{
GNREL
}

\section{Jamaican Domestic Ethanol Fuel Feasibility and Benefits Analysis}

\author{
Caley Johnson, Anelia Milbrandt, Yimin Zhang, \\ Rob Hardison, and Austen Sharpe
}

National Renewable Energy Laboratory

\section{Suggested Citation}

Johnson, Caley, Anelia Milbrandt, and Yimin Zhang, Rob Hardison, and Austen Sharpe. 2020. Jamaican Domestic Ethanol Fuel Feasibility and Benefits Analysis. Golden, CO: National Renewable Energy Laboratory. NREL/TP-5400-76011. https://www.nrel.gov/docs/fy20osti/76011.pdf

NREL is a national laboratory of the U.S. Department of Energy Office of Energy Efficiency \& Renewable Energy Operated by the Alliance for Sustainable Energy, LLC

This report is available at no cost from the National Renewable Energy Laboratory (NREL) at www.nrel.gov/publications.

Contract No. DE-AC36-08GO28308
Technical Report NREL/TP-5400-76011 May 2020

National Renewable Energy Laboratory 15013 Denver West Parkway Golden, CO 80401 303-275-3000 • www.nrel.gov 


\section{NOTICE}

This work was authored by the National Renewable Energy Laboratory, operated by Alliance for Sustainable Energy, LLC, for the U.S. Department of Energy (DOE) under Contract No. DE-AC3608G028308. Funding provided by the U.S. Department of State. The views expressed herein do not necessarily represent the views of the DOE or the U.S. Government.

This report is available at no cost from the National

Renewable Energy Laboratory (NREL) at

www.nrel.gov/publications.

U.S. Department of Energy (DOE) reports produced

after 1991 and a growing number of pre-1991

documents are available

free via www.OSTI.gov.

Cover Photos by Dennis Schroeder: (clockwise, left to right) NREL 51934, NREL 45897, NREL 42160, NREL 45891, NREL 48097, NREL 46526.

NREL prints on paper that contains recycled content. 


\section{Acknowledgments}

The authors would like to thank the following people and organizations for providing insight and technical input for this report: Dr. Betsy Bandy, Jamaica's Ministry of Science, Energy and Technology; Denise Tulloch, Niconor Reece, and Candice Edwards, Petroleum Corporation of Jamaica; Gerald Lindo, U.S. Agency for International Development; Uriel Green, Sugar Industry Authority; Lancelot White, Sugar Industry Research Institute; Lincoln Davy, All-Island Jamaican Cane Farmers Association; David Barrett, ENBAR Consulting; and Jayant Godbole and Shrikant Rathi, Praj Americas. 


\section{List of Acronyms}

ACP

CARDI

CEF

E10

E15

E25

EIA

EU

FAO

GDP

GDI

GHG

GOJ

GREET

LCA

LDV

MAF

MSET

NDC

NREL

OAS

PEL

SIA

STU

USDA
African, Caribbean and Pacific

Caribbean Agricultural Research and Development Institute

Cane Expansion Fund

$10 \%$ ethanol, $90 \%$ gasoline

$15 \%$ ethanol, $85 \%$ gasoline

$25 \%$ ethanol, $75 \%$ gasoline

Energy Information Administration

European Union

Food and Agricultural Organization

Gross domestic product

gasoline direct injection

greenhouse gas

Government of Jamaica

Greenhouse Gases, Regulated Emissions, and Energy Use in

Transportation

Lifecycle assessment

light-duty vehicle

Ministry of Agriculture \& Fisheries.

Ministry of Science, Energy, and Technology

Nationally Determined Contribution

National Renewable Energy Laboratory

Organization of American States

Petrojam Ethanol Company Limited

Sugar Industry Authority

Sugar Transformation Unit

U.S. Department of Agriculture 


\section{Executive Summary}

The Government of Jamaica asked the National Renewable Energy Laboratory (NREL) to determine if the use of domestically produced ethanol motor fuel could help them achieve their goals to develop its economy and to reduce greenhouse gas (GHG) emissions. The first step was to determine how much ethanol could be used by Jamaican vehicles in blends of $10 \%$ (E10 current blend level), 15\% (E15), or 25\% (E25). All blend levels make for feasible automotive fuels and are being used or pursued in multiple countries. Building on gross domestic product (GDP)-related projections made by the Johnson et al. (2019) business as usual scenario, the quantity of ethanol to be used in future years and blend levels is shown in Table ES1. All blend levels are assumed to achieve the same volumetric fuel economy because of verified efficiency improvements enabled by increased octane levels.

Table ES1. Current and Projected Ethanol Consumption in Jamaica (in million liters)

\begin{tabular}{|l|l|l|l|l|}
\hline Year & E10* & Ethanol in E10 & Ethanol in E15 & Ethanol in E25 \\
\hline 2018 & 759 & 76 & 114 & 190 \\
\hline 2030 & 838 & 84 & 126 & 209 \\
\hline 2050 & 1,063 & 106 & 159 & 266 \\
\hline
\end{tabular}

*Source of 2018 E10 volume: MSET 2019. Source of projections: Johnson et al. (2019)

The next step of the analysis was a resource assessment, which found sugarcane to be the most viable feedstock for domestic ethanol for the 2030 timeframe. A theoretical maximum was set at 288 million L/year of sugarcane ethanol under a scenario where the amount of land devoted to sugarcane is returned to its 1960 's levels of 60,000 ha and productivity is maximized at $4,800 \mathrm{~L} / \mathrm{ha} / \mathrm{yr}$. This theoretical maximum allows for all goal quantities of ethanol (as shown in Table ES1) to be achieved. Numerous additional scenarios were run that achieved the needed quantities of ethanol (per Table ES1) by increasing the hectarage of sugarcane production or the yield from current levels. Scenarios were laid out whereby required ethanol is produced by hectares of land and yield that Jamaica has achieved in previous years and domestic sugar needs are still met.

A lifecycle GHG impact assessment was then performed for utilizing domestic cane ethanol at the prescribed blend levels, using the Greenhouse Gases, Regulated Emissions, and Energy Use in Transportation (GREET) model. Replacing imported U.S. corn ethanol with domestic sugarcane ethanol in E10 is estimated to yield between 29\% and 57\% GHG savings. For E15 and E25, replacing $1 \mathrm{~L}$ of gasoline with $1 \mathrm{~L}$ of domestically produced sugarcane ethanol yields a 79.5\% GHG reduction. At a national level, the savings are estimated in Table ES2, with comparisons to Jamaica's Nationally Determined Commitment (NDC) goal.

Table ES2. Estimated GHG Savings from Domestic Sugarcane Ethanol in Various Blend Levels (tonnes $\mathrm{CO}_{2} \mathrm{e} / \mathrm{year}$ )

\begin{tabular}{|c|c|c|c|c|c|c|}
\hline & \multicolumn{3}{|c|}{2030} & \multicolumn{3}{c|}{2050} \\
\hline Fuel blend & E10 & E15 & E25 & E10 & E15 & E25 \\
\hline $\begin{array}{c}\text { Lifecycle GHG reductions - } \\
\text { Lower bound }\end{array}$ & 21,470 & 122,100 & 323,300 & 27,090 & 154,100 & 404,400 \\
\hline \% of NDC Goal* - Lower bound & $1 \%$ & $8 \%$ & $22 \%$ & na** & na** & na** \\
\hline
\end{tabular}




\begin{tabular}{|c|c|c|c|c|c|c|}
\hline & \multicolumn{3}{|c|}{2030} & \multicolumn{3}{c|}{2050} \\
\hline Fuel blend & E10 & E15 & E25 & E10 & E15 & E25 \\
\hline $\begin{array}{c}\text { Lifecycle GHG reductions - } \\
\text { Upper bound }\end{array}$ & 67,990 & 168,600 & 369,800 & 85,800 & 212,800 & 463,100 \\
\hline \% of NDC Goal* - Upper bound & $5 \%$ & $12 \%$ & $26 \%$ & na** & na** & na** \\
\hline
\end{tabular}

*NDC Goal (conditional) is to reduce emissions by $1,449,000$ tonnes $\mathrm{CO}_{2} \mathrm{e}$ in 2030 (10\% of total emissions). Jamaica's specified NDC calculations may deviate from LCA protocol.

** Jamaica has not yet set a 2050 goal

Next, an economic analysis of domestic ethanol production was performed. The analysis focused on the net decrease in foreign expenditures due to replacing foreign ethanol, gasoline, and crude oil with domestic ethanol. Foreign expenditures are required to purchase equipment and fuel for sugarcane farming, ethanol production facilities, vehicle fueling, and vehicle upgrades. These expenditures were accounted for in Table ES3, which displays the net decreases in foreign expenditures for these items. The table shows that the amount of money kept in the Jamaican economy, and therefore available to recirculate and increase GDP, ranges from \$60B to \$138B USD in 2030, depending on the chosen blend level.

Table ES3. Net Decrease in Foreign Expenditures Derived from Domestic Sugarcane Ethanol (mil USD)

\begin{tabular}{|l|c|c|c|c|c|c|}
\hline Target Year & \multicolumn{3}{|c|}{2030} & \multicolumn{3}{c|}{2050} \\
\hline Fuel Blend & E10 & E15 & E25 & E10 & E15 & E25 \\
\hline $\begin{array}{l}\text { Foreign fuel expenditures under E10 } \\
\text { business-as-usual scenario }\end{array}$ & $\$ 751$ & $\$ 751$ & $\$ 751$ & $\$ 1,620$ & $\$ 1,620$ & $\$ 1,620$ \\
\hline $\begin{array}{l}\text { Foreign gasoline expenditures with } \\
\text { domestic ethanol production }\end{array}$ & $\$ 675$ & $\$ 638$ & $\$ 563$ & $\$ 1,478$ & $\$ 1,396$ & $\$ 1,232$ \\
\hline Production facility capital costs* & $\$ 3.3$ & $\$ 5.0$ & $\$ 8.2$ & $\$ 4.2$ & $\$ 6.2$ & $\$ 10.5$ \\
\hline $\begin{array}{l}\text { Farming costs (fuel, fertilizer, pesticides, } \\
\text { machinery) }\end{array}$ & $\$ 7.5$ & $\$ 11.2$ & $\$ 18.7$ & $\$ 9.5$ & $\$ 14.2$ & $\$ 23.7$ \\
\hline $\begin{array}{l}\text { Biorefinery operating costs- fuels and } \\
\text { materials }\end{array}$ & $\$ 5.1$ & $\$ 7.7$ & $\$ 12.8$ & $\$ 6.5$ & $\$ 9.7$ & $\$ 16.2$ \\
\hline Fuel station preparation & $\$ 0.0$ & $\$ 0.3$ & $\$ 0.3$ & $\$ 0.0$ & $\$ 0.0$ & $\$ 0.0$ \\
\hline Vehicle incremental cost & $\$ 0.0$ & $\$ 0.0$ & $\$ 10.1$ & $\$ 0.0$ & $\$ 0.0$ & $\$ 6.7$ \\
\hline Net decrease in foreign expenditures & $\$ 59.6$ & $\$ 88.8$ & $\$ 138.0$ & $\$ 121.7$ & $\$ 193.8$ & $\$ 331.2$ \\
\hline
\end{tabular}

* Amortized over 30 years (facility life)

Overall, ethanol demands in 2030 can likely be met for all blend levels without needing to increase sugarcane hectarage beyond historic maximums and keeping yields within realistic bounds. The GHG reductions would be substantial, and domestic ethanol would keep up to \$138 million USD in the Jamaican economy that would otherwise be spent abroad. Scenarios for 2050 require additional feedstocks and yield increases but show even greater GHG and financial benefits. However, Jamaica would need to overcome some substantial hurdles such as low sugar yields, committing government funding for capital or encouraging private investment in infrastructure, and developing a conducive policy environment for transitioning equipment to support and utilize higher ethanol blends. 


\section{Table of Contents}

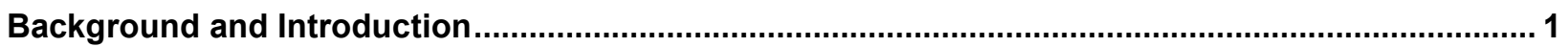

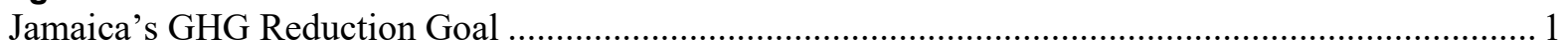

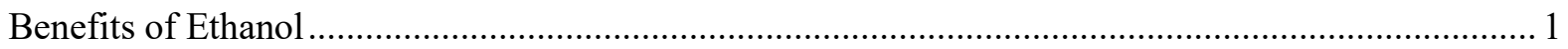

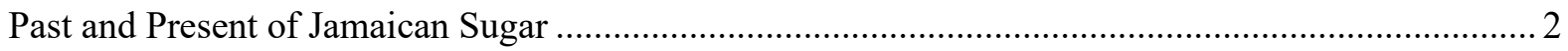

Ethanol Industry and the Onset of a National Biofuels Policy ....................................................... 4

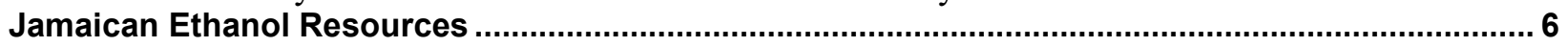

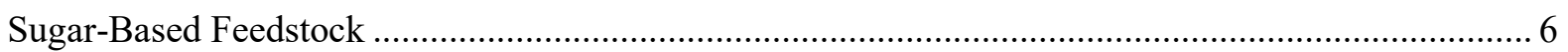

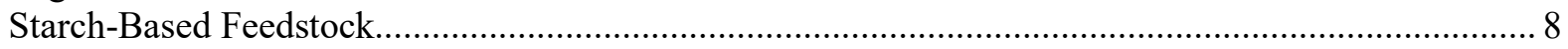

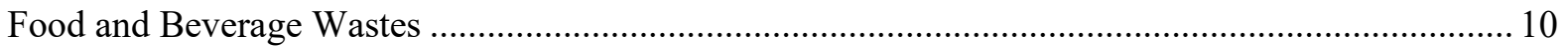

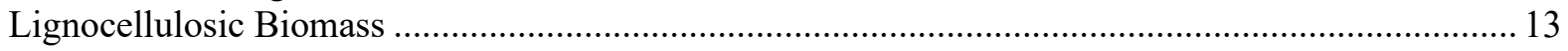

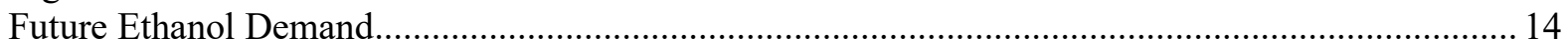

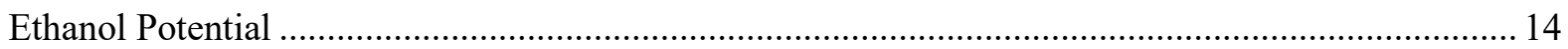

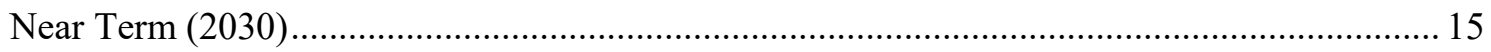

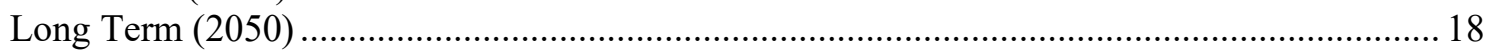

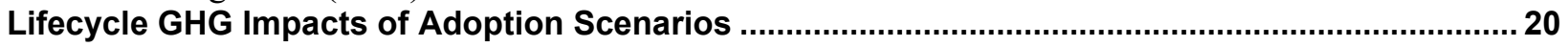

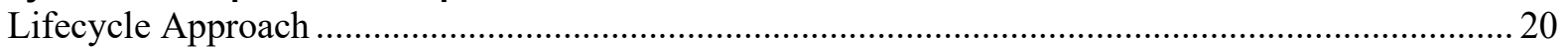

Current Sugarcane and Ethanol Production Practices ................................................................. 21

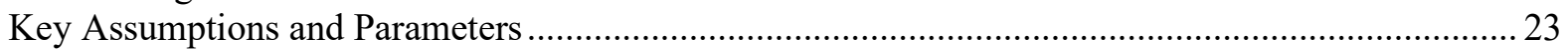

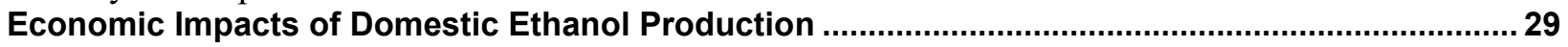

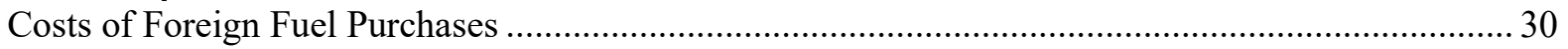

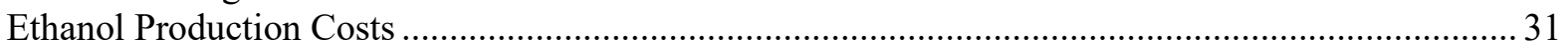

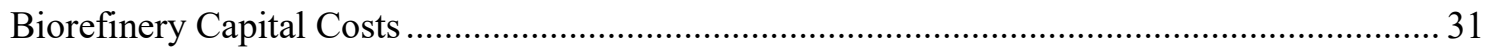

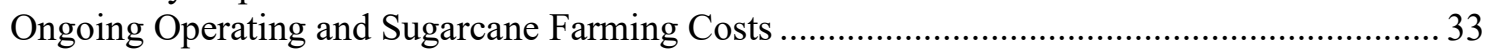

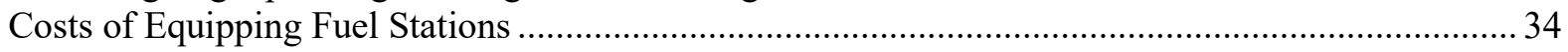

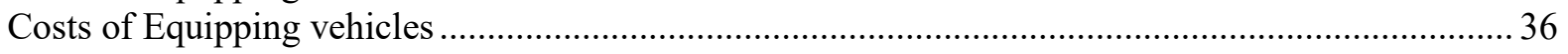

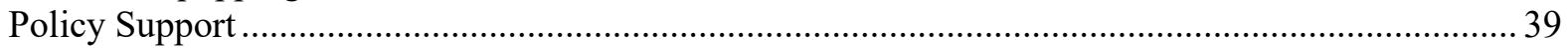

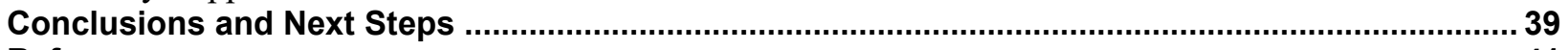

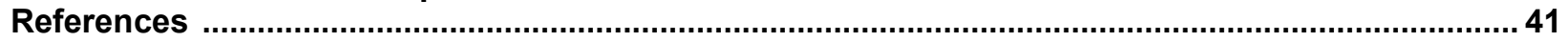




\section{List of Figures}

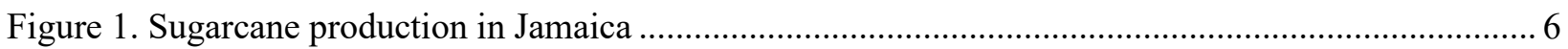

Figure 2. Sugarcane production areas and sugar factories ............................................................. 7

Figure 3. Illustrative overview of lifecycle activities associated with ethanol production ........................ 21

Figure 4. Impacts of selected operations on lifecycle GHG ............................................................. 29

Figure 5. Estimated capital costs for biorefineries required to meet domestic demand............................ 31

Figure 6. Primary components of a typical ethanol production facility ................................................ 32

Figure 7. Penetration of GDI and turbo technologies into the U.S. LDV market.................................... 37

\section{List of Tables}

Table ES1. Current and Projected Ethanol Consumption in Jamaica ..................................................... v

Table ES2. Estimated GHG Savings from Domestic Sugarcane Ethanol in Various Blend Levels............. v

Table ES3. Net Decrease in Foreign Expenditures Derived from Domestic Sugarcane Ethanol ................vi

Table 1. Jamaican Sugar Production Statistics: Peak vs. Present .............................................................2

Table 2. Advantages and Disadvantages of Different Forms of Cassava Feedstock ................................. 9

Table 3. Estimated Ethanol Quantities That Could be Produced from Food and Beverage Waste ............ 13

Table 4. Current and Projected Ethanol Consumption in Jamaica........................................................... 14

Table 5. 2030 Ethanol Resource Scenarios......................................................................................... 15

Table 6. Estimated GHG Savings from Domestic Sugarcane Ethanol in Various Blend Levels ............... 20

Table 7. Key Assumptions Associated with Sugarcane Production, Transportation, and Conversion....... 28

Table 8. Net Decrease in Foreign Expenditures Derived from Domestic Sugarcane Ethanol................... 29

Table 9. Projected E10 Consumption in Jamaica ................................................................................ 30

Table 10. Projected Amount Spent Fuel Imported to Jamaica, If No Domestic Ethanol Production......... 31

Table 11. Estimated Annual Operating Costs for Ethanol Production ..................................................... 33

Table 12. Estimated Annual Farming Costs for Ethanol Production......................................................... 34

Table 13. Expenditures for E25/E15 Compatibility Decrease as Time Passes and More Equipment

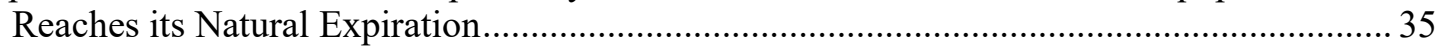

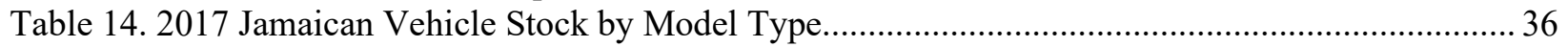

Table 15. Cost of Purchasing E25 Vehicles instead of E10 Vehicles in Jamaica...................................... 38 


\section{Background and Introduction}

Jamaica currently purchases nearly all of its transportation fuel (either raw or refined) from other countries, which constitutes a major financial outflow and a relatively high-greenhouse gas (GHG) fuel system. The Ministry of Science, Energy, and Technology (MSET) is weighing options to decrease both Jamaica's foreign expenditures and its GHG emissions. One option is to replace the ethanol used in the nationwide 10\% ethanol blend (E10) fuel. This would replace corn-based ethanol imported from the United States with domestic ethanol. Another option to further decrease GHG and foreign expenditures is to increase the blend level to $15 \%$ (E15) or 25\% (E25). The MSET has asked the National Renewable Energy Laboratory (NREL) to assess the feasibility of producing domestic ethanol for these blend levels, the associated reduction of lifecycle GHG emissions, and the net expenditures that would be redirected into the local economy.

\section{Jamaica's GHG Reduction Goal}

Jamaica has pledged to reduce its GHG emissions 10\% below its 2005 business-as-usual trajectory by 2030, subject to the provision of international support (Government of Jamaica 2015). One option to help it meet this goal is to blend ethanol into its gasoline). Jamaica phased in E10 from 2008 to 2010 so now all highway gasoline is E10 (Johnson et al. 2019). However, Jamaica is currently importing corn-based ethanol from the United States and blending it into gasoline to create its E10 (U.S. Energy Information Administration [EIA] 2019, MSET 2019, Petrojam 2019). The Government of Jamaica (GOJ) has requested that NREL investigate the potential GHG and economic benefits of using domestic ethanol derived from various local crops instead of imported ethanol derived from corn, and the impact of increasing the ethanol blend level of its gasoline to $15 \%$ or $25 \%$.

\section{Benefits of Ethanol}

Domestically produced ethanol has the potential to redirect money from international ethanol markets back into the domestic economy. Along with this redirection could come an increase in jobs, economic growth, and energy security. It also allows Jamaica to tap ethanol feedstocks (such as sugarcane) that have potentially lower lifecycle GHG emissions than corn-based ethanol (Wang et al. 2012). Lifecycle GHG emissions take into account GHG emissions from each stage of fuel production and use and are therefore the most direct proxy to global climate impact. Lifecycle accounting is the methodology required by the United States' Renewable Fuel Standard, California's Low Carbon Fuel Standard, European Union's (EU) Renewable Energy Directive, and other notable programs.

There are also potential benefits to increasing the ethanol blend level from E10 to E15 or even E25. Drivers could see the benefits of increased performance (in the form of increased acceleration, payload capacity, or towing capacity [Johnson et al. 2015]); potential fuel cost savings (through improved fuel economy and potential lower fuel prices); decreased price volatility; and lower GHG emissions. Vehicle manufacturers could also benefit from improved vehicle performance, including increased fuel economy. Refiners and fuel suppliers could see benefits from the use of ethanol as well. Ethanol is currently the most cost-effective source of incremental octane (OPIS and MathPro 2017). This could even allow for cost savings by using low-quality (lower octane) blendstock. Increasing from E10 to E25 can also contribute to cleaner 
air by reducing evaporative emissions (McCormick et al. 2014; Andersen et al. 2010). Furthermore, E15 and E25 could help to reduce tailpipe pollutants - especially, nonmethane hydrocarbons, 1-3 butadiene, benzene, and particulate matter (Anderson et al. 2014), as long as the base gasoline does not have a high level of aromatics (Yang et al. 2019).

\section{Past and Present of Jamaican Sugar}

The history of Jamaica's sugar industry gives context to its potential as a major supplier of ethanol and contributor to the local economy. The Jamaican sugar industry began in the early 1500 s under Spanish rule and grew to reach to peak production over the course of 450 years. By 1965, Jamaica ranked amongst the most prominent suppliers, laying claim to the largest export of raw sugar in the world. Since then, however, the industry's influence has declined, largely due to changes in international trade policy and production inefficiencies. The key barriers include deteriorating capital assets, lack of maintenance, losses from mechanical and supply deficiency, poor utilization of capacity, inefficient transportation infrastructure, and weather irregularities (Sugar Industry Authority [SIA] 2010). Jamaica's remaining sugar estates and their respective processing factories are challenged to maintain operationality, burdened by low export prices and dwindling supply.

In the 2017-2018 crop season, just five estates opened for production: Appleton, Frome, Golden Grove, Worthy Park, and Monymusk (which did not produce any cane of its own). In the absence of the Everglades factory, which ceased production in 2017, farmers from Trelawny and St. James were required to travel twice as far to deliver their cane. For some farmers, the additional distance and related costs proved prohibitive to business. This trend of closures has resulted in regional decline of supply and increased economic hardship.

Prior to 2006, Jamaica and other African, Caribbean and Pacific (ACP) countries received privileged access to the European sugar market. The enabling policy, The EU Sugar Protocol (EUSP), allowed ACP countries to secure high export prices for domestically produced sugar while benefiting from lower import prices for the foreign equivalent. In 2006, the EU replaced the EUSP with the ACP Economic Partnership Agreement, reducing ACP countries' prior price advantage by $36 \%$. The local industry suffered another blow when the EU opted to discontinue its sugar quota, a policy that had provided consist demand for Jamaican sugar. The combined loss, though drawn out over a lengthy transition period and softened, to an extent, by the EU's provision of financial aid under the Accompanying Measures for Sugar Protocol, forced Jamaica to compete on a level playing field with larger, more efficient producers, such as Brazil (Ministry of Agriculture \& Fisheries [MAF] 2014).

Table 1. Jamaican Sugar Production Statistics: Peak vs. Present

\begin{tabular}{|c|c|c|c|c|c|c|}
\hline Year & $\begin{array}{c}\text { Hectares } \\
\text { Harvested } \\
\text { (ha) }\end{array}$ & $\begin{array}{c}\text { Factories } \\
\text { in } \\
\text { Operation }\end{array}$ & Yield (tonnes) & $\begin{array}{c}\text { Raw Sugar } \\
\text { (tonnes) }\end{array}$ & $\begin{array}{c}\text { Harvest } \\
\text { Productivity } \\
\text { (tonnes cane/ha) }\end{array}$ & $\begin{array}{c}\text { Cane Productivity } \\
\text { (tonnes cane/ } \\
\text { tonnes sugar) }\end{array}$ \\
\hline $\mathbf{1 9 6 5}$ & 59,773 & 18 & $4,731,941$ & 516,825 & 79.17 & 9.16 \\
\hline $\mathbf{2 0 1 7}$ & 19,503 & 5 & $1,133,353$ & 87,993 & 58.11 & 12.88 \\
\hline
\end{tabular}

*Source of 1965 numbers- SIA (2010); Source of 2017 numbers- SIA (2017). 
To reverse the industry's decline, the Jamaican government began seeking opportunities to revitalize the sector. In 2005, a report entitled the Jamaica Country Strategy for the Adaptation of the Sugar Industry 2006-2015 (SAS; revised to extend into 2020) decreed a reduction in governmental control over the production and operation of the country's largest sugar mills. The plan heralded competition as a quintessential part of the industry's revival and advocated for the transition of mills to private ownership (MEM 2010). Furthermore, it sought to support a future where domestic cane production could sustain local sugar, molasses, rum, and budding biofuels industries in conjunction (MEM 2010). As a result, cane factories transitioned to the hands of companies such as Complant International of China in anticipation of receiving an economic boost. Production targets for the transition included 200,000 tonnes of raw sugar, 130,000 tonnes of molasses, and up to 70 million liters of hydrous ethanol per year (SIA 2010). However, as indicated in Table 1, the production levels for sugar are still far below aspirational quantities. A similar transition from public to private ownership was attempted previously in the 1990s and also experienced pitfalls.

To realize its goals for the industry, the government created the Sugar Transformation Unit (STU) in 2009, tasked with funneling resources from the newly established Cane Expansion Fund (CEF) into projects to improve production efficiency and the long-term sustainability of local sugar production (STU 2009). As of 2014, the STU had allocated grants and loans worth a total of U.S.\$1.6 billion to help farmers across the country (MOA 2014).

The Jamaican sugar industry now consists of two main actors: large estates that grow and produce their own sugar, and independent farmers that sell their cane to estates as feedstock. As of the 2017-2018 crop year, there were five operational estates and 2,751 farmers supplying supplemental cane. This number represents a $13 \%$ decrease from the previous year due to a factory closure and the growing impact of prohibitive costs (All-Island Jamaica Cane Farmers' Association 2018). As estates cease production, farmers once regionally linked to a production facility face significantly increased transport distances, the ramifications of which include new and tighter timelines for harvesting as well as budget increases for the carriage of goods. During the 2016-2017 year, after the closure of the Everglades factory, some 52,108 tonnes of cane from local farms required redistribution to other factories (SIA 2017). As previously mentioned, such redistribution has ruined the business case in the past.

Over the course of its existence, the research division of SIA (SIRI) has undertaken a number of projects to inform the future of the industry. As stated in its 2017 Annual Report (SIA 2017), the key research objectives moving forward are to a) develop productive cane varieties, b) improve farming systems and production management, c) look into soil health and nutrition management, d) develop reliable means of agrometeorological forecasting, e) understand agrochemical use and impacts, f) improve factory efficiency and technology, and g) improve harvesting logistics.

In collaboration with the West Indies Sugarcane Breeding and Evaluation Network, SIRI continues to engage in research to produce an array of strains best suited for the variety of Jamaican growing contexts. Since receiving special funding to develop and test ways to increase field productivity through machinery and cultivation best practices, SIRI has begun experimentation with the most promising varieties attained from the Variety Development Program in comprehensive agricultural environments (SIA 2017). 


\section{Ethanol Industry and the Onset of a National Biofuels Policy}

In pursuit of more diverse solutions to the declining industry, the government began investigating the potential for biofuels to augment the value of sugar. By producing ethanol for domestic consumption in addition to raw sugar, the market for cane would expand and direct economic resources both to the struggling industry and vast quantity of individuals it supports. Before deriving a local production scheme, however, the government needed a domestic market for ethanol.

With this goal in mind, in 2009, Jamaica established an E10 mandate to require all gasoline to contain $10 \%$ ethanol. To accommodate the law, the country imported hydrous ethanol from established producers in Brazil and the United States and began investing in dehydration facilities to ready the liquid fuel for end-use (MEM 2010). The country still depends on ethanol imports today, but shifts in the international market have decreased the reliability of supply and the burden of import taxes continues to weigh on purchasers (Potopsingh 2016).

Following the E10 mandate, the government instated the National Biofuels Policy to spur exploration and expansion of biofuels into 2030. In alignment with the National Energy Policy, it has goals related to sustainability, intersectoral collaboration, technology development, legal framework, and capacity building (MEM 2010).

To better understand the potential to integrate fuel production into the sugar industry, the government commissioned a study from the Organization of American States (OAS) and Winrock International as a part of the Global Bioenergy Partnership. The culminating report, published in 2011, reaffirms the prospect that abandoned land previously used for sugar, if recultivated, could satisfy the production needs for sugar, rum, and E10. The report concludes that sugarcane is well positioned to act as the primary feedstock should Jamaica develop a domestic biofuels industry. Achieving greater production, however, would warrant diversification of the cane varieties currently bred and grown. The report encourages Jamaica to experiment with varieties that have higher total sugar ${ }^{1}$ content (good for ethanol), higher bagasse content (good for electricity generation), and staggered stages of maturity (to prolong the harvesting season). Encouraging these traits is identified by the report as the foremost step in pursuit of a viable ethanol industry and economic revival of sugarcane (OAS 2011).

In 2016, the government furthered this research with the Report on Potential Ethanol Feedstocks (Potopsingh 2016). The major takeaways support prior findings that sugarcane, amongst a myriad of feedstock options, serves as the most promising pathway to domestic ethanol production. During this time, the Ministry of Science, Technology, Energy, and Mining continued to work closely with OAS in the Global Bioenergy Partnership to develop an understanding of the social impacts of biofuel production. The report, released in 2015 , examined the implications of bioelectricity generation at Golden Grove and anhydrous ethanol production from molasses at Everglades and concluded that local ethanol production would indeed have a beneficial impact on both worker and community stakeholders (OAS 2015).

\footnotetext{
${ }^{1}$ As opposed to high sucrose content.
} 
However promising the production landscape of sugarcane ethanol, as of the writing of this report, there is no domestic fuel ethanol production taking place in Jamaica. The sale of government estates to private companies, thought to spur the construction of ethanol plants, among other upgrades and repairs, never saw pilot projects through to scale (SIA 2010). Around the release of the Report on Potential Ethanol Feedstocks (Potopsingh 2016), news of a Floridabased renewable energy company constructing a 10-million-gallon ethanol plant spread through the media. An article from The Gleaner reported the need for 4,000 hectares of land to grow the sweet sorghum - the intended feedstock (Thame 2016). The deal in question seemed imminent, with reference to approval from members of the government and Petrojam, but no evidence of a sorghum ethanol plant appears in the press or government reports thereafter. In 2017, The Gleaner released another article speaking to the interest that Jamaican-owned entity Yallahs International Inc. had in acquiring the Monymusk Sugar Factory. Part of the intent, the author claims, was to expand production to include ethanol (Titus 2017), but updates on these proceedings could not be found.

Despite its recent attention, ethanol is not a new investment for Jamaica. According to Petrojam 2009, interest in the biofuel dates back to the 1970s and early 1980s. This is when the Caribbean Basin Economic Recovery Act, also known as the Caribbean Basin Initiative, of 1983 offered Caribbean nations with select, duty-free sales to U.S. commodity markets-including ethanol. The government-owned Petroleum Corporation of Jamaica took note and began efforts to establish a Caribbean-based ethanol production scheme. By 1987, the Petroleum Corporation of Jamaica, operating through its subsidiary Petrojam Ethanol Limited (PEL), purchased the struggling Bernard Lodge Sugar Factory and built fermentation and distillation facilities capable of processing 15 million gallons of ethanol per year. The facility subsisted off domestic as well as international supply sourced from other Caribbean nations in addition to Europe and Brazil. An increase in the required contributions of Caribbean Basin Initiative countries compelled Petroleum Corporation of Jamaica to either augment its domestic supply or outsource to another eligible country. Ultimately, local production was not able to meet the expressed need, so the company arranged to lease a sugar factory in Belize. This lasted until 1997.

The operability of domestic ethanol facilities has fluctuated significantly since implementation of, and changes to, the Caribbean Basin Initiative. Cost constraints have shuttered fermentation efforts and recently, dehydration as well (MSET 2019b). Inefficiency caused one of PEL's two dehydration plants to shut down, and technological obsolescence eventually suspended the third. European-owned facilities supplied with surplus wine alcohol from the European Commission enabled a momentary revival, but this ceased in 2004 as Europe began developing its own biofuels industry domestically. In search of a reliable and economical feedstock, PEL partnered with Brazil's Coimex Trading Company in 2005 to invest in a new 40-million gallon/year, dehydration facility (Petrojam Ethanol Limited 2009). Unfortunately, The Gleaner reported in 2017 that the plant, now fully owned by PEL, has gone unused since 2013 due to an imbalance in the overall cost vs. benefits procured (Campbell 2017).

It is apparent that to revive Jamaica's sugar industry and establish a robust ethanol industry will require a redoubled effort. Before putting forth such an effort, it is worth stepping back to make sure that sugarcane is the desired feedstock and to assess Jamaica's potential for switching to other resources. 


\section{Jamaican Ethanol Resources}

Ethanol is produced from a variety of organic sources. These include sugar crops and products (e.g., sugarcane, sugar beets, sweet sorghum, molasses), starches (e.g., corn, wheat, grain sorghum, cassava, potatoes), food and beverage wastes (e.g., cheese whey, potato waste, brewery waste), and lignocellulosic material (e.g., crop residues such as corn stover, wheat straw, bagasse, rice husk, and native grasses). Many of these materials are produced in Jamaica. The current production and ethanol potential for these resources in the country are summarized below.

\section{Sugar-Based Feedstock}

Sugarcane is a tropical and sub-tropical perennial grass of the genus Saccharum grown primarily for sugar production. Sugarcane production in Jamaica has been declining, apart from occasional spikes, and reached an all-time low level in 2017 at about 1.1 million tonnes (Figure 1). As a reference, sugarcane production in the 1970s was between 3 million tonnes and 4 million tonnes annually, during the 1980s and 1990s it dropped to about 2 million annually, and continued its downward trend until recent years (SIA 2019a; Food and Agricultural Organization [FAO] 2019a). Harvested area has also decreased over time, from about 60,000 ha during the $1960 s$ and 1970 s to about 20,000 ha in recent years (SIA 2019a). The sugarcane yield in Jamaica fluctuates over the years, with values between 50 and 80 tonnes/ha during the last several decades (FAO 2019a). The average yield during the past 11 years is about 55 tonnes/ha, reaching almost 60 tonnes/ha several times during that period. As a reference, sugarcane yield in Brazil, the world's largest producer of sugarcane, has been consistently over 70 tonnes/ha since the late 1990s. Yield depends partially on the growing season, which is 165170 days in Jamaica (Jalgaonkar 2019).

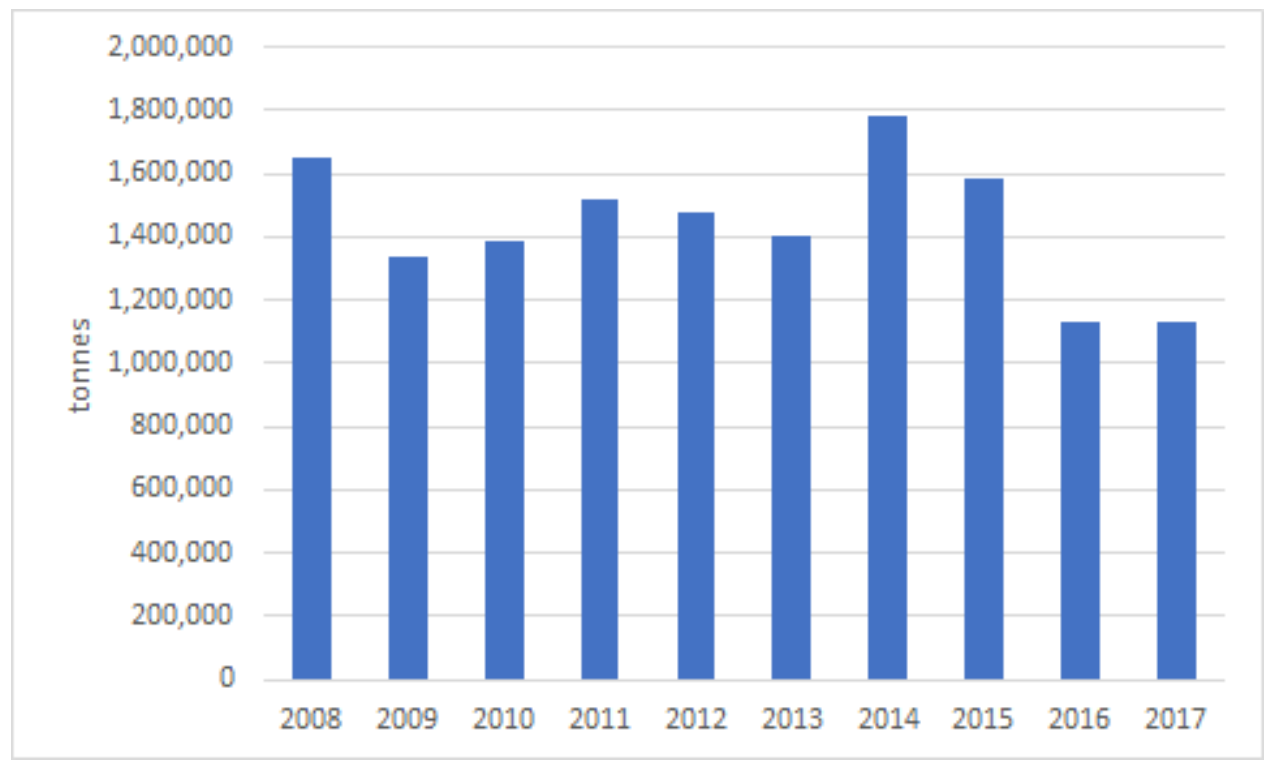

Figure 1. Sugarcane production in Jamaica

Source: Sugar Industry Authority (2019a) 
Figure 2 illustrates the sugarcane-producing areas and factories in Jamaica. The factories at the six estates process the sugarcane into raw sugar and molasses. The estate factories process about $42 \%$ of the sugarcane produced in the country (USDA 2018a). The remaining portion comes from nearby farmers who sell their crop to these facilities. With the recent closure of the Everglades Farms' factory, sugarcane from the Trelawny and St. James parishes have been transported to other processing facilities, namely Appleton, Worthy Park, Monymusk, and Frome (SIA 2018). It is expected that this factory closure will result in somewhat reduced production in the surrounding area due to the high transportation costs related to selling the sugarcane to another mill (USDA 2018a).

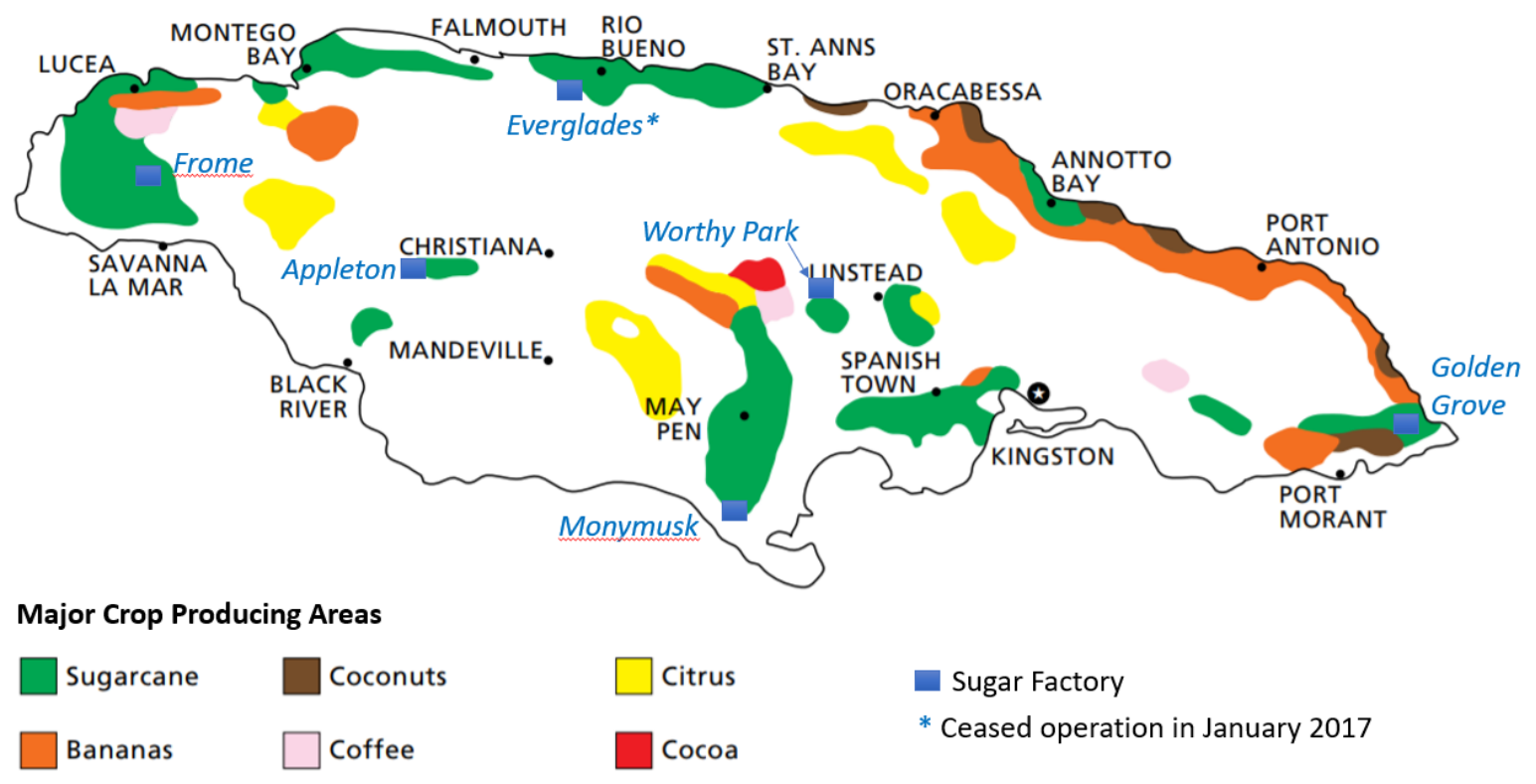

Source: FAO (2013), USDA (2018a)

Figure 2. Sugarcane production areas and sugar factories

Ethanol potential from sugarcane varies depending on crop productivity and conversion efficiency. Ethanol potential has been estimated to be between 3,200-9,600 liters/ha, assuming crop productivity between 40 and 120 tonnes/ha/yr. and about 80 liters/tonne of sugarcane (Wang et al. 2018). Given sugarcane yield between 50 and 60 tonnes/ha/yr. in Jamaica during the past 40 years, ethanol potential in the country could be in the range of 4,000-4,800 liters/ha/yr. An upper bound for sugarcane ethanol production can therefore be set under an aggressive assumption if the amount of land returns to historic levels of 60,000 ha and productivity is maximized at 4,800 L/ha/yr., which results in a theoretical maximum of 288 million L/year of sugarcane ethanol. Of course, this maximum is most likely not realistic, and more realistic scenarios will be explored in the next section of this report.

Sweet sorghum refers to varieties of sorghum (Sorghum bicolor) developed primarily for the harvest of juice. Similar to sugarcane, sweet sorghum juice is high in sugar and is extracted from the stalks for further processing into sugar and alcohol. The crop has also been identified as a promising ethanol feedstock throughout the tropical and temperate zones of the world for several 
reasons: it is drought-tolerant, thus can be grown on marginal lands; its short growth period (3-5 months) makes it suitable for cultivation twice a year or as a complementary feedstock to sugarcane; it can be used as an alternative crop in areas where sugarcane does not perform well; and it can utilize the existing harvest and processing infrastructure (Barcelos et al. 2016). In addition, the crop produces not only juice, but also grains and lignocellulosic biomass - the grains could be easily fermented into ethanol and the bagasse, and harvesting residues could be used to produce cellulosic ethanol via advanced conversion processes thus could supplement sugar-based ethanol production. Sweet sorghum yield ranges from 32 to 112 tonnes/ha depending on many factors such as climate conditions (e.g., temperature, precipitation), soil quality, cultivar, and production practices (Ekefre et al. 2017). As a reference, its grain yield is about 3-7 tonnes/ha, although the crop is not grown for the purpose of grain production (Almodares and Hadi 2009).

Sweet sorghum is not currently grown in Jamaica. A media release in 2016 indicates that a sweet sorghum-to-ethanol project led by Benchmark Renewable Energy was planned in the country, growing the crop on some 4,000 ha with expected yield of 50 tonnes/ha (total of 100 tonnes/ha from two harvests annually) (JAMPRO 2016). While this project has not yet been implemented, it indicates that background work was performed leading to conclusions that sweet sorghum is suitable for Jamaica's agro-climatic conditions.

Ethanol potential from the juice of sweet sorghum has been estimated to be between 3,000 and 8,000 liters/ha depending on harvest frequency (once or twice per year), crop productivity, and conversion efficiency (Almodares and Hadi 2009, UKY 2013, Ekefre et al. 2017). This potential is estimated to be higher if sweet sorghum grains and bagasse are also used for ethanol production - about 13,600 liters/ha from the conversion of sugary, starchy, and lignocellulosic fractions (Barcelos et al. 2016).

Molasses is a byproduct of sugar crop processing - the liquor remaining after crystallization of the sugar juice. It is a dark-colored, viscous, and sugar-rich liquid, used primarily in the production of alcohol beverages, as a livestock feed additive, and for direct human consumption. Molasses is also used for fuel ethanol production in Thailand, Indonesia, India, and China. One tonne of molasses yields between 220 and 290 liters of ethanol (Bhatia 2014; Lavarack 2003; USDA 2006a).

Currently, molasses in Jamaica is used primarily in the production of rum. The rum industry consumes about 100,000 tonnes of molasses per year, of which 50\% is imported due to limited local supply (USDA 2006a; Medley 2019). Given the yield above, and as stated by Medley 2019, Jamaica produces between 20 million and 22 million liters of rum each year. The six distilleries operating in the country today import molasses from Fiji, Guatemala, Mexico, and countries in South America.

\section{Starch-Based Feedstock}

Jamaica grows several grain and root crops suitable for ethanol production. These include corn, rice, cassava, sweet potatoes, and yams. However, these crops are produced at a small scale, used locally for human consumption, and export is very limited. Thus, it is unreasonable to suggest fuel ethanol production from these resources unless for the excess/export portion or damaged crops (e.g., partially decayed, affected by fungi or insects, unfit for human consumption) are 
considered. A discussion about cassava as a feedstock for ethanol production is provided below due to a planned increase in production.

Cassava (Manihot esculenta) is a root vegetable cultivated throughout the tropical parts of the world. It is a staple food and a good source of nutrients from which cassava flour, breads, tapioca, and alcoholic beverages are produced. While cassava yield in Jamaica has remained stable over the past 20 years at about 19 tonnes/ha, the harvested area has dropped by almost half, from about 900 ha on average in the 1990s and early 2000s to about 500 ha in the past few years (FAO 2019). Production has been fluctuating over the past 20 years, averaging 16,000 tonnes/yr. with occasional spikes to 20,000 tonnes/yr. during that period. However, during 2016 and 2017, cassava production was at an all-time low level, at about 10,000 tonnes/yr. (FAO 2019). Cassava's advantages and disadvantages as an ethanol feedstock are outlined in Table 2.

Ethanol is produced from three forms of cassava: fresh roots, dried chips, and starch. Each feedstock has advantages and disadvantages, as illustrated in Table 2. Ethanol yield for fresh roots is estimated between 150 and 180 liters/tonne or between 1,800 and 7,200 liters/ha assuming crop productivity between 10 and 40 tonnes/ha/yr. (Kuiper et al. 2007; Li and Wei 2006). Given the current cassava yield at about 19 tonnes/ha in Jamaica, ethanol potential from fresh roots in the country could be about 3,600 liters/ha/yr. Ethanol yield for dry cassava chips is estimated between 333 and 460 liters/tonne (Kuiper et al. 2007; Sriroth et al. 2012). Ethanol yield for starch has not been assessed in a context relevant to Jamaica.

Table 2. Advantages and Disadvantages of Different Forms of Cassava Feedstock

\begin{tabular}{lll}
\hline Form & \multicolumn{1}{c}{ Advantages } & \multicolumn{1}{c}{ Disadvantages } \\
\hline & & - Not available for whole year, seasonally \\
& & harvested \\
Fresh & - Low cost during harvest & - Bulky, costly to transport \\
roots & - Less costly to remove soil \& sand & - Cannot be stocked / short shelf-life due to \\
& nutrients and minerals that are & - Difficult to adjust total dry solid content in \\
& advantageous to yeast fermentation & a fermentor \\
& & - Limit total dry solid content for high solid \\
& & loading or very high gravity (VHG) \\
& - Extended shelf-life & fermentation \\
& - Can be stored & - Higher cost than fresh roots \\
Dried & - Less costly for transportation & - Must be dried before stored \\
Chips & - Can be processed by applying & - High soil \& sand contamination \\
& conversion technology of corn & - Limit total dry solid content for high solid \\
& loading or very high gravity (VHG) \\
& grains & fermentation \\
& - Less costly to stock & - High feedstock cost \\
& - Less costly to transport & - High production cost \\
Starch & - Easy to adjust total solid content in & - Loss of nutrients during starch extraction \\
& a reactor and prepare high solid & process \\
& loading slurry & - High demand in other production of \\
& valued products \\
\hline
\end{tabular}

Adopted from Sriroth et al. 2012. 


\section{Food and Beverage Wastes}

Food and beverage wastes, such as cheese whey, brewery waste, citrus waste, banana waste, expired or off-spec food and beverage products, and wastes from flour and starch manufacturing, are another type of feedstock for ethanol production. While these applications are typically at small scale, they can still contribute to a local economy and towards overall ethanol production goals. This feedstock is relatively inexpensive, is easily accessible, and could reduce competition with staple food. Jamaica's food-processing sector is underdeveloped, relying heavily on imported ingredients (Food Export 2019). The alcoholic beverage sector, represented primarily by rum and beer production, is well developed in the country. The ingredients for rum production (molasses) are sourced locally and through imports, while those for beer production (barley malt syrup) are mostly imported, though efforts are underway to substitute part of imported barley with locally produced cassava. The non-alcoholic beverage sector is relatively well developed, and it is focused mainly on the production of fruit juice sourced locally, consumed domestically, and exported.

Cheese whey, the liquid by-product of milk coagulation during cheese production, is generated in large volumes. This material could be used to produce ethanol as it has been demonstrated by few companies in the United States and Europe, e.g., Golden Cheese Co. of California and Quexeria Bama in Spain (Sims 2007; Navarro 2008). Dairy Industries Jamaica Ltd., located in Kingston, appears to be the largest dairy-processing facility in Jamaica. The company produces several brands of cheese, but no information is available on its capacity or annual production, thus it is difficult to estimate the amount of cheese whey that could be available at this facility (Dairy Industries Jamaica Ltd. 2019). On average, it takes about 10 liters of milk to make $1 \mathrm{~kg}$ of hard cheese (Cheese Board 2019). Softer varieties require less milk, about 7 liters per kg, and it appears that Jamaican cheese is soft (Jamaica Observer 2017). The consumption of milk and milk substitutes in Jamaica accounts for more than 60 million liters annually, of which $20 \%$ is sourced domestically (Patterson 2016). If we assume that between 5\% and 10\% of milk consumption in the country is used for cheese production, between $429,000 \mathrm{~kg}$ and $857,000 \mathrm{~kg}$ of cheese is produced in Jamaica annually. About 10 liters of cheese whey are generated for each $\mathrm{kg}$ of cheese manufactured; thus, the amount of cheese whey in the country could be in the range of 4.3 and 8.6 million liters per year (Díez-Antolínez et al. 2018). Lactose content in cheese whey is about $0.05 \mathrm{~kg} /$ liter, on average, thus between $215,000 \mathrm{~kg}$ and $430,000 \mathrm{~kg}$ of lactose could be generated annually (Koushki 2012). On average, about $1.58 \mathrm{~kg}$ of lactose would be needed to produce a liter of ethanol, depending on conversion efficiency (Ling 2008). Thus, the ethanol production from cheese whey in Jamaica could be in the range of 136,000-272,000 liters.

Brewery waste includes several types of material: solid (brewer's spent grains, or BSG), semisolid (spent yeast or yeast slurry), and liquid (expired, spilled or off-spec beer). BSG is the major by-product of the brewing industry, representing around $85 \%$ of the total by-products generated (Mussatto et al. 2006). It is composed primarily of husk and seed coat layers. About $20 \mathrm{~kg}$ of wet BSG are produced per 100 liters of beer produced (González-García et al. 2018; Mussatto et al. 2006). BSG are typically used as animal feed and composting, but can also be used as feedstock for ethanol production. Its potential has been researched extensively, but it has not been commercialized. 
In the process of fermenting beer, leftover yeast forms at the bottom of the fermentation vessel. This material could be used to produce ethanol as it has been demonstrated by a few companies in the United States, e.g., Wind Gap Farms and Sierra Nevada Brewing Company in partnership with E-Fuel Corp (Sims 2007; ProBrewer 2007). The conversion process practiced by Wind Gap Farms involves the following steps: once the beer waste is collected, the company removes the alcohol, dries it, and denatures the residual alcohol into ethanol. The dried yeast is sold to the pet food industry, where it is used as a nutritional supplement and flavor enhancer (Sims 2007). Between 1.5 and $3 \mathrm{~kg}$ of spent yeast are generated for every 100 liters of beer produced (Mathias et al. 2017). There are two breweries in Jamaica: the major one is Desnoes and Geddes Ltd. (best known for its Red Stripe and Dragon brands of beer) and Razz Brewery (a small-scale local producer), both located in Kingston (Leonard 2018). The Food and Agricultural Organization (FAO) reports that beer production in the country is about 94 million liters annually (FAO 2019b). This volume corresponds to roughly 1.4 million $\mathrm{kg}$ and 2.8 million $\mathrm{kg}$ of spent yeast. Wind Gap Farms stated that it produces about 1.9 million liters of ethanol per year using about 4.5 million $\mathrm{kg}$ of spent yeast, which is equivalent to about $2.4 \mathrm{~kg}$ of spent yeast per liter of ethanol (Sims 2007). Using this yield, Jamaica could potentially produce between 583,000 and 1.2 million liters of ethanol annually from spent yeast.

Expired, spilled, or off-spec beer is another waste material that can be used for ethanol production. This process has been demonstrated by the MillerCoors brewing company in the United States at its adjacent ethanol recovery facility constructed by Merrick \& Company, which has been in operation since 1996. The brewery produces about 2.3 billion liters of beer annually of which about 7.3\% (168 million liters) results in waste beer (Sims 2008; Merrick \& Company 2019). The ethanol recovery facility turns that waste beer into 11.4 million liters of 200-proof ethanol each year, which is blended locally with gasoline. The conversion process is described as follows: "The plant receives brewing residuals such as spilled or off-spec beer, which is about 6 percent alcohol. Residuals are heated and distilled in a stripper to increase the ethanol content. After the ethanol is further concentrated through a second step of distillation in the rectifier, the remaining water is extracted in a molecular sieve, and wastewater is sent to a treatment plant concurrently throughout the process." (Sims 2008). Using the waste beer-to-ethanol conversion ratio based on MillerCoors/Merrick's experience, about 14.7 liters of waste beer could produce a liter of ethanol. If we assume that about $5 \%$ of current beer production in Jamaica results in waste beer, this volume corresponds to about 4.7 million liters which could result in about 320,000 liters of ethanol.

Cassava processing waste. Major products from cassava in Jamaica include bammy (a traditional Jamaican flatbread), gari (coarser cassava grits), cassava flour, and cassava starch. Waste material from the processing of cassava into these products includes peels and pulp (also called cassava pomace or bagasse), which are typically used as animal feed, scattered on fields, or simply disposed of as trash. Between $250 \mathrm{~kg}$ and $300 \mathrm{~kg}$ of peels per tonne of cassava are produced when processing the crop into flour and starch (Ogbonna et al. 2018). In addition, about $400 \mathrm{~kg}$ of pulp per tonne of cassava are produced when processing the crop into starch (Ogbonna et al. 2018). The Ministry of Agriculture \& Fisheries reports that there were a total of 11 major cassava processors in 2012, most of them producing bammies (MAF 2015). Our research reveals that of those 11 facilities, only five are currently operating, and one of them (Jamaica Producers Tropical Foods) is producing chips; thus, no flour or starch is produced on site. The four bammy factories in operation today are: Twickenham Bammy Industries in St. 
Catherine, Flower Hill Cooperative in St. James, Tihule Company in Clarendon, and Central Food Packers Ltd. in St Catherine. Based on a survey conducted by MAF in late 2012, the monthly quantity used by the 11 cassava processors was about $322,315 \mathrm{~kg}(3,868$ tonnes per year) (MAF 2015). An updated survey in January 2015 indicates a significant drop in cassava processing by these factories, about $99,614 \mathrm{~kg}$ per month (1,195 tonnes per year), due to lack of reporting by one of the major processors and decline in cassava supply (MAF 2015).

A study by the Caribbean Agricultural Research and Development Institute (CARDI) indicates that in 2012, there were no dedicated cassava flour nor cassava starch factories in the country (CARDI 2013). However, during 2014-2015, the Government constructed a factory in Goshen, St Elizabeth, to produce cassava and sweet potato flour to supply the local baking industry, which is capable of processing more than 18 tonnes of tubers in a week (JIS 2014, The Gleaner 2016). In addition, Desnoes and Geddes Ltd. began operating a cassava starch processing plant at its headquarters in mid-2015 (Campbell 2015). The pilot plant has a capacity of 20 tonnes per day, and the company is expecting to produce 960 tonnes of cassava starch per year (Heineken 2019; MyVueNews 2015).

It is safe to assume that cassava flour is produced and consumed on site at the four bammy factories mentioned above, as well as at the dedicated cassava flour factory in Goshen. Thus, these facilities are likely generating peels as waste. The cassava starch processing plant at Desnoes and Geddes Ltd. (Red Stripe) is also generating pulp in addition to cassava peels. If we assume that about 600 tonnes of cassava are processed annually today (about half of the quantity processed in 2015 due to closure of several locations and a decline in cassava supply), between 150 and 180 tonnes of peels could be available from processing cassava into flour at the four bammy factories. If we assume that Red Stripe's pilot plant processes between 3,500 and 5,500 tonnes of cassava into starch annually (roughly between $50 \%$ and $75 \%$ capacity), on average, between 950 and 1,500 tonnes of peels and between 1,400 and 2,200 tonnes of pulp could be available at that location. Ethanol potential from cassava peels and pulp is estimated to be between 180 and 318 liters per tonne, or about 250 liters per tonne on average (Ogbonna et al. 2018; Mithra et al. 2018; Martinez et al. 2018). Thus, between 625,000 and 970,000 liters of ethanol could be produced from cassava processing waste (peels and pulp) in Jamaica. However, the use of these resources for ethanol production is still in the nascent stage of development. In the spring of 2018, the Nordic energy group St1 completed the construction of a pilot plant in Thailand that produces advanced ethanol for transportation using cassava pulp as feedstock (St1 2018). The pilot plant will be operated for a year in several starch factories to test different environments, conditions, and seasonal changes, which will be essential to finalizing the concept for a full-scale ethanol production facility. In 2013, a small-scale ethanol microdistillery (400 to 500 liters per day, $\geq 90 \%$ alcohol by volume) was constructed in Nigeria to produce ethanol using primarily cassava peels as feedstock (Loto 2013; Green Social Bioethanol 2019).

Citrus processing waste (e.g., pulp, peels, rag, and seeds) is what remains after juice extraction of fruits such as orange, lime, lemon, grapefruit, tangerine, etc. In addition to soluble sugars, citrus waste contains cellulose, hemicellulose, and pectin, which can be hydrolyzed into sugars and fermented into ethanol. In addition, citrus peels contain limonene (used as a flavor, fragrance, and industrial solvent), which could be recovered as a co-product during the conversion process, generating revenue stream to offset some of the production cost (Zhou et al. 
2007). While there are no commercial ethanol facilities using citrus waste, the conversion process has been extensively researched and demonstrated at a pilot scale by the U.S.

Department of Agriculture's Agricultural Research Service (USDA 2006b). Moreover, for optimal feedstock use, the integrated production of ethanol, biogas, pectin, and limonene from citrus wastes has been investigated by Pourbafrani et al. in 2010. Their research concluded that one tonne of citrus waste with $20 \%$ dry weight could generate about 40 liters of ethanol, $45 \mathrm{~m}^{3}$ methane, 9 liters of limonene, and $39 \mathrm{~kg}$ pectin.

Jamaica produces a variety of citrus fruits for domestic consumption and export. Local companies such as Trade Winds Citrus Ltd. and Ojay Koolers manufacture and distribute juices; thus, citrus waste is generated at those locations. Jamaica produced about 147,000 tonnes of citrus fruits in 2017 (FAO 2019c). If we assume that 30\% of this production is used in the beverage industry and considering that waste accounts for about $50 \%$ of fresh fruit weight (Mamma and Christakopoulos 2008), about 22,000 tonnes of citrus processing waste could be generated in Jamaica. Using the conversion ratio to ethanol from Pourbafrani et al. (2010), this amount corresponds to roughly 880,000 liters of ethanol.

In summary, we estimate that waste from the food and beverage industries in Jamaica could provide feedstock for 1.96 to 2.44 million liters of ethanol, as broken down in Table 3 . This quantity could potentially be added to the total fuel ethanol pool of Jamaica without any required land use changes, although the upper threshold only fulfils $0.3 \%$ of the 2018 ethanol fuel demand.

Table 3. Estimated Ethanol Quantities That Could be Produced from Food and Beverage Waste

\begin{tabular}{|l|r|r|}
\hline Feedstock & Low Estimate (L) & High Estimate (L) \\
\hline Cheese Whey & 136,000 & 272,000 \\
\hline Brewery Waste & 320,000 & 320,000 \\
\hline Cassava Waste & 625,000 & 970,000 \\
\hline Citrus Waste & 880,000 & 880,000 \\
\hline Total & $1,961,000$ & $2,442,000$ \\
\hline
\end{tabular}

\section{Lignocellulosic Biomass}

Lignocellulosic biomass is the most abundant type of biomass and includes various organic material such as wood, grasses, and agricultural and municipal wastes. It is chemically composed of cellulose, hemicellulose, and lignin that can be processed into diverse energy products, one of which is ethanol. Lignocellulosic materials in Jamaica include woody biomass (currently used in the form of charcoal or firewood), sugarcane harvesting residues (e.g., tops and leaves, also called trash), sugarcane processing waste (bagasse), cassava harvesting residues (leaves and stems), cassava processing waste (e.g., peels and pulp) discussed earlier, and BSG, which were also discussed earlier.

The main lignocellulosic biomass resource in Jamaica is sugarcane bagasse, the fibrous residue remaining after stalks are crushed to extract their juice. Bagasse is currently used on site to produce steam for the sugar factories. Total bagasse generation was estimated at about 335,000 tonnes in the 2017-2018 crop year (SIA 2019b). Ethanol yield from bagasse could be in the 
range of 149 to 180 liters/tonne (Bezerra and Ragauskas 2016). Thus, Jamaica could produce between 49.9 and 60 million liters of cellulosic ethanol per year. Different pretreatment and hydrolysis options have varying effects on glucose concentration available for fermentation, contributing to the variation in ethanol production levels (Bezerra and Ragauskas 2016).

Similar to other lignocellulosic materials, sugarcane bagasse has low nutritional value, which prevents concerns about the food versus fuel debate (Bezerra and Ragauskas 2016). However, commercialization of cellulosic ethanol globally has been somewhat slower than anticipated for various reasons related to infrastructure (e.g., fuel distribution), technical barriers (e.g., variable composition of biomass), feedstock supply and logistics, and more prominently, economics (plant construction and ethanol production are costly despite available financial assistance).

\section{Future Ethanol Demand}

To put Jamaica's ethanol resources into perspective, future demand needs to be determined. This report builds on, E10 projections made by Johnson et al. 2019, which link vehicle kilometers travelled to GDP growth projections. These are shown in Table 4, in addition to calculated quantity of ethanol demand. These projections assume that volumetric fuel economy parity between the three blend levels is achieved. The necessary fuel efficiency improvements needed to compensate for lower energy density of ethanol are possible because the increased octane of ethanol allows for higher compression ratios in the pistons, which creates more power that can be directed to greater fuel efficiency. Fuel economy parity would require $\sim 4 \%$ efficiency improvement to make up for reduced energy density in E25 and $\sim 2 \%$ for E15. This has been demonstrated in laboratories (Szybist et al. 2010; Szybist and West 2013; Leone et al. 2014; Splitter and Szybist 2014a\&b; Leone et al. 2015; West et al. 2018) and is a goal of many auto manufacturers selling to the U.S. market (McCormick 2016).

It should be noted that the overall demand for ethanol in any blend could be reduced by transportation efficiency and electrification measures laid out in Johnson et al. 2019. Such measures would reduce the corresponding required harvested area or yield in the scenarios below.

Table 4. Current and Projected Ethanol Consumption in Jamaica (in million liters)

\begin{tabular}{|l|c|c|c|c|}
\hline Year & $\mathrm{E}^{*}{ }^{*}$ & Ethanol in E10 & Ethanol in E15 & Ethanol in E25 \\
\hline 2018 & 759 & 76 & 114 & 190 \\
\hline 2030 & 838 & 84 & 126 & 209 \\
\hline 2050 & 1,063 & 106 & 159 & 266 \\
\hline
\end{tabular}

*Source of 2018 E10 volume: MSET 2019. Source of projections: Johnson et al. 2019

\section{Ethanol Potential}

To achieve sustainable domestic ethanol production in Jamaica, the industry would have to ensure that it does not compromise the feedstock supply for the local food and beverage industries. In the near term (2030), increasing established crops' production (such as sugarcane) would be more practical than introducing new crops (such as sweet sorghum) or new technologies (such as cellulosic ethanol), which would take time to develop and 
would introduce additional risks. New crops and technologies could be investigated and tried during the timeframe in preparation for a long-term development. In the near term, Jamaica could also consider ethanol production from food and beverage waste, particularly those that have been implemented worldwide: cheese whey; spent brewer's yeast; and expired, spilled or off-spec beer. While these applications will not contribute significantly toward Jamaica's overall ethanol production goals (total estimated potential is between 2 and 2.4 million liters per year), they could have valuable social impact such as local job development and waste management solutions.

To meet the projected ethanol demand (illustrated in Table 4) using domestically produced ethanol, several scenarios are discussed below. It should be noted that the overall demand for ethanol in any blend could be reduced by transportation efficiency and electrification measures laid out in Johnson et al. (2019). Such measures would reduce the required harvested area or yield in the scenarios below.

Near Term (2030)

The 2030 ethanol requirements laid out in Table 4 can be met multiple ways while meeting other sugar demands, keeping the hectares devoted to sugarcane production within historical limits, and improving yield to varying degrees. These scenarios are summarized in Table 5 and described below.

Table 5. 2030 Ethanol Resource Scenarios

\begin{tabular}{|c|c|c|c|c|c|}
\hline $\begin{array}{l}\text { Blend } \\
\text { Level }\end{array}$ & $\begin{array}{c}\text { Ethanol } \\
\text { Quantity } \\
\text { (ML) }\end{array}$ & Non-ethanol sugar & $\begin{array}{c}\text { Required } \\
\text { Hectares } \\
\text { ('000) }\end{array}$ & $\begin{array}{c}\text { Required } \\
\text { Yield } \\
\text { (t/ha) }\end{array}$ & Scenario \\
\hline \multirow{5}{*}{ E10 } & \multirow{5}{*}{84} & \multirow{3}{*}{$100 \mathrm{kt}$ (+50kt molasses) } & 45 & 50 & $1 a$ \\
\hline & & & 37 & 60 & $1 b$ \\
\hline & & & 32 & 70 & $1 c$ \\
\hline & & \multirow{2}{*}{$200 \mathrm{kt}$ (+100kt molasses) } & 57 & 60 & $2 a$ \\
\hline & & & 49 & 70 & $2 b$ \\
\hline \multirow{5}{*}{ E15 } & \multirow{5}{*}{126} & \multirow{3}{*}{ 100kt (+50kt molasses) } & 55 & 50 & $3 a$ \\
\hline & & & 46 & 60 & $3 b$ \\
\hline & & & 39 & 70 & $3 c$ \\
\hline & & \multirow{2}{*}{$200 \mathrm{kt}$ ( $+100 \mathrm{kt}$ molasses) } & 66 & 60 & $4 a$ \\
\hline & & & 57 & 70 & $4 b$ \\
\hline \multirow{3}{*}{ E25 } & \multirow{3}{*}{209} & \multirow{2}{*}{$100 \mathrm{kt}(+50 \mathrm{kt}$ molasses $)$} & 64 & 60 & $5 a$ \\
\hline & & & 55 & 70 & $5 b$ \\
\hline & & 200kt (+100kt molasses) & 72 & 70 & $6 a$ \\
\hline
\end{tabular}


There are a number of ways that Jamaica could meet the projected E10 demand of 84 million L ethanol in 2030. The following scenarios, which were chosen for their variety of hectarage and yield, could be explored:

1. To supply feedstock for raw sugar domestic consumption and export (100,000 tonnes annually), assuming that they stay flat, and supply half of the molasses the local rum industry needs (50,000 tonnes annually), the country could consider the following options:

a. Increase sugarcane harvested area to about 45,000 ha, as it was in the 1980 s, and maintain yield at about $50 \mathrm{t} / \mathrm{ha}$

b. Increase sugarcane harvested area to about $37,000 \mathrm{ha}$, as it was in the late 1990 s, and increase yield to about $60 \mathrm{t} / \mathrm{ha}$

c. Increase sugarcane harvested area to about 32,000 ha, as it was in the early 2000 s, and increase yield to about $70 \mathrm{t} / \mathrm{ha}$.

2. To double the feedstock for raw sugar domestic consumption and export $(200,000$ tonnes annually) and supply the entire amount of molasses the local rum industry needs (100,000 tonnes annually), thus avoiding the current practice of importing this material, the country could consider the following options:

a. Increase sugarcane harvested area to about 57,000 ha, as it was in the early 1970 s, and increase yield to about $60 \mathrm{t} / \mathrm{ha}$

b. Increase sugarcane harvested area to about $49,000 \mathrm{ha}$, as it was in the late 1970 s, and increase yield to about $70 \mathrm{t} / \mathrm{ha}$.

For Jamaica to meet the projected $\mathbf{E 1 5}$ demand of 126 million L of ethanol in 2030, the following scenarios could be explored:

3. To supply feedstock for raw sugar domestic consumption and export (100,000 tonnes annually), assuming that they stay flat, and supply half of the molasses the local rum industry needs (50,000 tonnes annually), the country could consider the following options:

a. Increase sugarcane harvested area to about 55,000 ha, as it was in the late $1960 \mathrm{~s}$, and maintain yield at about $50 \mathrm{t} / \mathrm{ha}$

b. Increase sugarcane harvested area to about 46,000 ha, as it was in the 1980 s, and increase yield to about 60 t/ha

c. Increase sugarcane harvested area to about 39,000 ha, as it was in the past, and increase yield to about $70 \mathrm{t} / \mathrm{ha}$.

4. To double the feedstock for raw sugar domestic consumption and export $(200,000$ tonnes annually), and supply the entire amount of molasses the local rum industry needs (100,000 tonnes annually), thus avoid import of this material, the country could consider the following options:

a. Increase sugarcane harvested area to about $66,000 \mathrm{ha}$, as it was in the past, and increase yield to about $60 \mathrm{t} / \mathrm{ha}$

b. Increase sugarcane harvested area to about 57,000 ha, as it was in the 1970 s, and increase yield to about $70 \mathrm{t} / \mathrm{ha}$.

For Jamaica to meet the projected E25 demand of 209 million L ethanol in 2030, the following scenarios could be explored:

5. To supply feedstock for raw sugar domestic consumption and export (100,000 tonnes annually), assuming that they stay flat, and supply half of the molasses the local rum 
industry needs (50,000 tonnes annually), the country could consider the following options:

a. Increase sugarcane harvested area to about 64,000 ha, as it was in the 1970 s, and increase yield to about $60 \mathrm{t} / \mathrm{ha}$

b. Increase sugarcane harvested area to $55,000 \mathrm{ha}$, as it was in the late $1960 \mathrm{~s}$, and increase yield to about $70 \mathrm{t} / \mathrm{ha}$.

6. To double the feedstock for raw sugar domestic consumption and export $(200,000$ tonnes annually) and supply the entire amount of molasses the local rum industry needs (100,000 tonnes annually), the country could consider the following option:

a. A substantial increase in sugarcane harvested area to about 72,000 ha, as it was in early 1960s, and increase yield to about $70 \mathrm{t} / \mathrm{ha}$.

While cassava is well established in Jamaica and is suitable for ethanol production, the above scenarios exclude this crop for several reasons: 1) Countries using cassava as feedstock for ethanol production are either major producers of the crop with sufficient amounts to supply the food, beverage and fuel industries (e.g., Nigeria, Thailand), or major importers with large local production as well (namely China). 2) Cassava is primarily used for food in Jamaica, and production has always been marginal or low; thus, using the crop for fuel production would place the industry in direct competition with food sources. 3) The use of cassava for beer production as a replacement for imported barley in recent years is somewhat controversial as it impacts bammy production, which already struggles with feedstock shortage (Jamaica Star 2019); thus, introducing another industry in the mix may not be strategic in the near term. This is not to say that cassava does not have potential as an ethanol feedstock in Jamaica in the long term. The crop could be used in combination with other feedstocks, but that would require policies and regulations to ensure a balance between food security and fuel.

The above scenarios also exclude grains such as corn and rice that are grown in Jamaica because production levels are low, and using these materials as feedstock for ethanol production would compete directly with food sources. Countries using grains as feedstock for ethanol production such as the United States, Brazil, and China have large domestic production and excess volumes; thus, they can afford to produce ethanol without a major impact on the food supply. However, China has stopped developing new plants using grains and now focuses on other feedstock such as cassava, sweet sorghum and cellulosic biomass ( $Y u$ et al. 2014). As mentioned earlier, damaged crops (e.g., partially decayed, affected by fungi or insects, unfit for human consumption) could be considered as an alternative source; however, given the limited production of grains in the country, it is unlikely that the amount would be sufficient to provide a stable supply for refineries.

Molasses is also excluded from the scenarios above because of low domestic production. It supplies only half of the local rum industry's demand, which relies on import for its remaining needs. Thus, using molasses for ethanol production would compromise the beverage industry's feedstock supply, and it is unlikely that this resource would play a role in the near term. In the long term, however, molasses could be used as an ethanol feedstock if the country's production of raw sugar increases. As a reference, some of the largest sugarcane producing countries in the world - Thailand, India, and China - use molasses instead of sugarcane as ethanol feedstock as they find it more economical. 


\section{Long Term (2050)}

Given the long timeframe, many different scenarios could be explored by 2050. Jamaica could still consider primarily sugarcane expansion or a combination of sugarcane with other sources such as sweet sorghum and lignocellulosic material (e.g., sugarcane bagasse and trash), even some amounts of cassava and molasses if an excess production is reached by then. For example, to meet the projected E10 demand of 106 million L of ethanol in 2050, supply double the amount of today's feedstock needed for raw sugar domestic consumption and export $(200,000$ tonnes annually), and supply the entire amount of molasses the rum industry needs (100,000 tonnes annually), thus avoiding import of this material, the country could consider the following options:

1. Increase sugarcane harvested area to about 62,000 ha, as it was in the $1960 \mathrm{~s}$, and increase yield to about $60 \mathrm{t} / \mathrm{ha}$

2. Increase sugarcane harvested area to about 53,000 ha, as it was in the past, and increase yield to about $70 \mathrm{t} / \mathrm{ha}$

3. Increase sugarcane harvested area to about 56,000 ha, as it was in the $1960 \mathrm{~s}$, and increase yield to about $60 \mathrm{t} / \mathrm{ha}$; in addition, allocate 5,000 ha to sweet sorghum production and maintain two harvests annually

4. Double today's sugarcane production and use bagasse and trash to produce cellulosic ethanol.

Various other combinations of these and other materials could be applied to meet projected E10, E15, and E25 demand by 2050. It is beyond the scope of this study to provide all possible options.

One of the main considerations for Jamaica in the long term could be refineries' feedstock flexibility. This is the direction China, a country with aggressive ethanol production and consumption goals, is taking. New and planned ethanol plants in the country are feedstock flexible and can choose from cassava, sweet sorghum, and lignocellulosic biomass ( $\mathrm{Li}$ et al. 2017; Yu et al. 2014). Another example is India where sweet sorghum is used as a complementary feedstock in sugar mills producing ethanol (International Crops Research Institute for the Semi-Arid Tropics 2017). Feedstock flexibility provides refineries with market stability: when feedstock prices increase or supply is short, a multi-feedstock plant can switch to an alternative and continue production.

If Jamaica is interested in developing sugarcane-based ethanol, best practices and lessons learned could be derived from Brazil, which has the most successful sugarcane ethanol industry in the world. Many factors contributed to the country's success that can be grouped under two categories: the Brazilian government's large investment in infrastructure and research. Under the National Alcohol Programme (Pro-Álcool) launched in 1975, the Brazilian government invested in increasing agricultural production, modernizing and expanding distilleries, establishing new production plants, introducing subsidies to lower prices and reduced taxes for ethanol producers (Almeida 2007). Key developments in agricultural research included varieties adapted to different soil and climate conditions with shorter production cycles, better yields, and tolerance to water scarcity and pests (Almeida 2007). Three types of production facilities exist in Brazil that reflect the country's strategy regarding concurrent sugar and ethanol production: 1) sugar 
mills (producing only sugar), 2) mills with distillery plants (sugar and ethanol production), and 3 ) independent distilleries (only ethanol production) (Hofstrand 2009).

Extensive research on sweet sorghum has been conducted worldwide during the past 10 to 15 years and abundant knowledge has been obtained regarding breeding, genetics and variety selection, crop physiology, and production techniques (e.g., irrigation, fertilizer use, nutrient uptake, plant density, etc.) (Yang et al. 2018). However, sweet sorghum-based ethanol production remains in the research and exploratory phases of commercialization (USDA 2018b). China is one of the leading countries researching and developing sweet sorghum as a non-food feedstock for fuel ethanol (Liu et al. 2014). China's first sweet sorghum ethanol plant started operation in June 2014 in Inner Mongolia, supplying fuel to three cities, but high operating costs have limited expansion of production capacity (USDA 2014, USDA 2018b). Sweet sorghum has also been established in India, and as mentioned earlier, it is being used as complementary feedstock in sugar mills producing ethanol. Brazil has also considered sweet sorghum as a complementary feedstock as it can extend the ethanol production season by up to 60 days in the country (Green Car Congress 2015). Nigeria also recently announced that it will begin producing ethanol and glucose syrup from sweet sorghum: the project is a result of several years testing Chinese-origin sweet sorghum varieties across several states to ensure robustness in the local environment and positive responses to diseases and pests (Sapp 2019). Ethanol and glucose syrup are produced domestically from cassava in Nigeria, but demand for the crop as a food staple means prices are too high to be a viable feedstock (Sapp 2019).

As mentioned earlier, commercialization of cellulosic ethanol globally has been somewhat slower than anticipated. The first commercial-scale facilities became operational during 20122016 (ETIP Bioenergy 2019). The largest facilities in the world are listed below, but there are a number of smaller demonstration plants that are either operational or under development in the United States, Brazil, China, Italy, Denmark, Finland, etc. (ETIP Bioenergy 2019).

- DuPont, Iowa, USA, 83,000 tons per year capacity, startup in 2016, currently idle (ETIP Bioenergy 2019).

- POET-DSM Advanced Biofuels, Iowa, USA, 75,000 tons per year capacity, startup in 2014, operational (ETIP Bioenergy 2019).

- Abengoa Bioenergy Biomass of Kansas, Kansas, USA, 75,000 tons per year capacity, startup in 2014, ceased operations in late 2015 due to company's financial problems independent of the plant (ETIP Bioenergy 2019).

- GranBio, Alagoas, Brazil, 65,000 tons per year capacity, startup in 2014; operations were halted in 2016 after complications in the pretreatment of its sugarcane load forced the shutdown. The plant resumed operations in early 2019 and is expected to produce about 30 million liters of ethanol in 2019 and 50 million liters in 2020 (ETIP Bioenergy 2019; Kennedy 2019).

- Longlive Bio-technology Co. Ltd, Shandong, China, 60,000 tons per year capacity, startup in 2012, ceased operations in 2018 (ETIP Bioenergy 2019, USDA 2018b).

Cellulosic ethanol faces logistical challenges to supply reliable volumes of feedstock at low cost, and the technology conversion to commercial scale faces significant hurdles (USDA 2018b). The industry worldwide faces technical challenges, such as high levels of foreign matter in feedstocks and optimizing the use of enzymes to convert cellulosic material to energy, as well as 
compliance issues: processors struggle to comply with local regulations for air and water waste management (USDA 2018b).

\section{Lifecycle GHG Impacts of Adoption Scenarios}

Every liter of imported corn-based ethanol that is replaced by domestic sugar-based ethanol reduces GHG emissions by $29 \%-57 \%$. Similarly, for every liter of gasoline that is replaced by domestic ethanol in E15 and E25, GHGs are reduced by nearly 80\%. These GHG reductions are tallied in Table 6 for three different ethanol blend levels based on the projected ethanol and gasoline consumption for the years 2030 and 2050 (see Table 4), with explanations following in this section.

Table 6. Estimated GHG Savings from Domestic Sugarcane Ethanol in Various Blend Levels (tonnes $\mathrm{CO}_{2} \mathrm{e} /$ year)

\begin{tabular}{|l|c|c|c|c|c|c|}
\hline & \multicolumn{3}{|c|}{2030} & \multicolumn{3}{c|}{2050} \\
\hline Fuel blend & E10 & E15 & E25 & E10 & E15 & E25 \\
\hline $\begin{array}{l}\text { Lifecycle GHG reductions- } \\
\text { Lower bound }\end{array}$ & 21,470 & 122,100 & 323,300 & 27,090 & 154,100 & 404,400 \\
\hline NDC Goal*- Lower bound & $1 \%$ & $8 \%$ & $22 \%$ & na** $^{* *}$ & na $^{* *}$ & na** $^{*}$ \\
\hline $\begin{array}{l}\text { Lifecycle GHG reductions- } \\
\text { Upper bound }\end{array}$ & 67,990 & 168,600 & 369,800 & 85,800 & 212,800 & 463,100 \\
\hline NDC Goal*- Upper bound & $5 \%$ & $12 \%$ & $26 \%$ & na $^{* *}$ & na $^{* *}$ & na $^{* *}$ \\
\hline
\end{tabular}

${ }^{*}$ Nationally Determined Contribution (NDC) Goal (conditional) is to reduce emissions by $1,449,000$ tonnes $\mathrm{CO}_{2} \mathrm{e}$ in 2030 (10\% of total emissions). Jamaica's required NDC calculations may deviate from lifecycle assessment protocol.

** Jamaica has not yet set a 2050 goal.

Table 6 provides an illustrative comparison of the lifecycle assessment (LCA)-based calculations adopted in this analysis and the GHG emissions reduction goals established by Jamaica for the purposes of meeting its Nationally Determined Contribution (NDC) commitments under the 2017 Paris Climate Accord. The general methodologies for calculating NDC commitments are established by the Intergovernmental Panel on Climate Change (IPCC), but utilize specific emission factors and procedures determined by member governments. Without access to those Jamaica-specific factors and procedure, this report does not estimate the implications that domestic ethanol production would have on Jamaica's NDC commitments.

\section{Lifecycle Approach}

The LCA methodology is often used to assess the environmental impacts associated with a product, process, or activity by the identification and quantification of energy and materials flows used, as well as emissions released. The approach has been utilized as a standard to estimate lifecycle GHG emissions of biofuels, e.g., ethanol. Figure 3 shows a schematic overview of the typical lifecycle (well-to-wheel) of ethanol produced from biomass such as sugarcane, corn, and sorghum. The scope of the LCA usually takes into consideration the agricultural (including cropping, harvesting, and other relevant operations such as irrigation, field burning); transport; conversion of feedstock to biofuel such as ethanol; transport of the fuel through distribution; and fuel use stages. In addition to direct emissions from these lifecycle 
stages, upstream emissions, such as emissions associated with manufacturing of synthetic fertilizers, petroleum refining of crude oil to produce diesel, and electricity generation, are also accounted for in the LCA. Land use change could also be a significant GHG contributor if forest land or other land that stores a large amount of carbon is converted to sugarcane farming. However, without a detailed country-specific analysis to compare land use and soil carbon prior to and after the establishment of a new sugarcane ethanol industry in Jamaica, hypothetical numbers on land use change-related GHG emissions are not considered useful. As such, we do not include GHG emissions from land use change in the LCA.

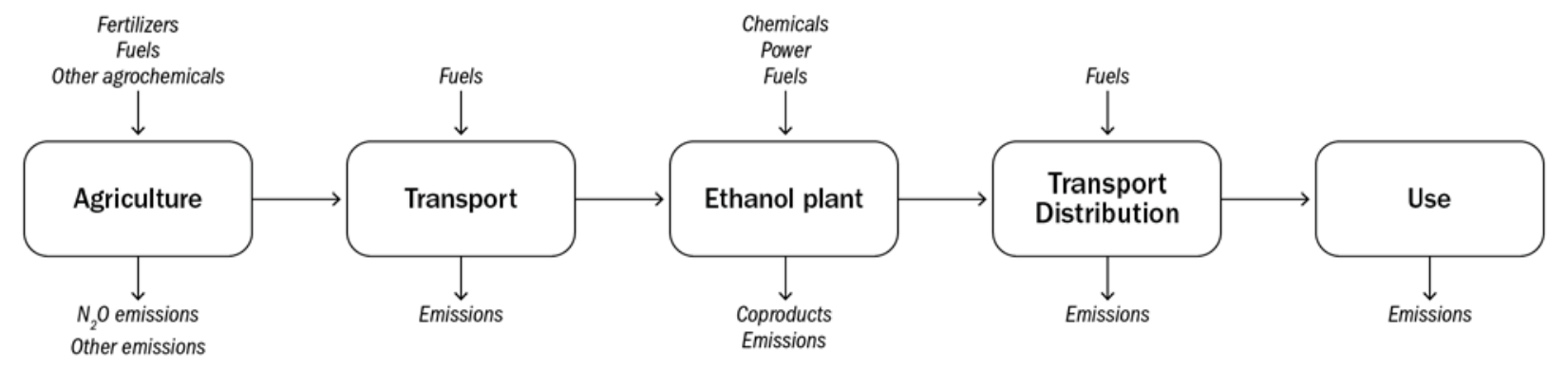

Figure 3. Illustrative overview of lifecycle activities associated with ethanol production

The intent of the national $10 \%$ ethanol in gasoline mandate was to source a significant percentage of the ethanol from local feedstock (sugarcane) in the short to medium term. Sugarcane is one of the most efficient photosynthesizers and is recognized to yield highest output to input ratio for biofuel engenderment (Khan et al. 2017). To understand whether switching from imported ethanol to ethanol produced from domestic sugarcane could provide environmental benefits in terms of lifecycle GHG emissions and fossil energy consumption, we first carry out a lifecycle analysis for Jamaican sugarcane production. Because sugarcane ethanol is not currently produced in Jamaica, we use Brazilian sugarcane ethanol production as a proxy by assuming the new industry in Jamaica will follow the Brazilian best practices learned over the decades.

\section{Current Sugarcane and Ethanol Production Practices}

To accurately estimate the lifecycle GHG emissions from sugarcane and ethanol production in Jamaica, we document the current sugar cane practices and ethanol production status.

Seeding: The majority of farms in Jamaica are seeded by hand, meaning that little to no mechanical energy is spent in the process. Ratooned (harvested) stalks can last four crop seasons before significantly diminishing in yield, thereby reducing seeding needs year to year.

Dressing: Satisfactory fertilization of sugarcane requires the use of approximately $12.550 \mathrm{~kg}$ bags per hectare (Bandy 2019), accompanied by additional dressings of urea, sulfate of ammonia, lime, herbicide, and pesticide to bolster the crop's viability. The most common blends of fertilizer are 14-28-14 for plant cane and 16-9-18 or 17-0-20 for ratoons, and the most used weedicides are Terbutryn and Diuron. While fertilizer and other dressings can increase yield, the improvement comes at a cost that not all cane producers can bear. Many farms forego a full dressing for financial reasons and suffer lower yields as a result. During the 2017-2018 season, farmers and estates reaped a total of 18,558 hectares of cane field. According to this number, 
approximately 231,975 bags of fertilizer ought to have been utilized. Upon further examination of actual usage as depicted in the 2017 All-Island Cane Farmers' Association Annual Report, the total bag equivalent amounted to a mere 22,892. Though manure and filter cake are not included in these totals, the dramatic difference in value sheds light on the challenges' farmers face to meet standard fertilization quota.

Irrigation: Certain locations and weather patterns enable farms to subsist on rainfall alone while others require the aid of irrigation to achieve viable yields. Exact numbers for the use of irrigated vs. rainfed systems are not available as farms often adapt their water usage to other cost barriers. However, at any given point, an estimated $60 \%$ of fields utilize one or more mechanical irrigation techniques (Davy 2019). In the regions of Jamaica that require supplemental water supply, flood and drip irrigation systems powered by electricity or small diesel generators are most commonly used. No information is available on water and energy consumption for sugarcane irrigation.

Harvesting: Cane fields utilize a mixture of mechanical and manual harvesting techniques with estates engaging in more mechanized recovery due to economies of scale. Overall, an estimated $80 \%$ of fields are subject to mechanical harvesting tactics. Despite the objective productivity of mechanized labor, some topographies render manual efforts more effective than machines. As a result, farms use a mixed or semi-mechanized approach to maximize their recovery of stalks.

Pre-harvest burning, though commonly acknowledged as a public health hazard, remains a widespread practice in Jamaica. Currently, an estimated $95 \%$ of Jamaican sugar farms engage in burning to rid cane stalks of the extra leafy biomass, known as trash, prior to reaping. Upon examining their inventory of cane and determining a net needed supply, factories will issue an order to burn. Farms with an established quota - assigned to them at the beginning of the growing season - may then burn enough to accommodate a portion of that professed need. Illicit burns are a common occurrence as well with employees keen to work despite dwindling demand. Due to the non-negligible health and environmental impacts, major sugar-producing countries such as Brazil have implemented comprehensive bans on burning.

Rather than burn cane trash, farmers may elect to leave it in the fields or recover it for use as part of the sugar production process. When left behind, trash can serve as a weed control mechanism and when harvested, either jointly or separate from the sugar-rich stalks, trash, along with bagasse, can serve as feedstock for the biomass generators that provide energy to the factories. Though useful and better for local air quality, these practices are labor-intensive and not without cost. In 2017, the research division of the SIA conducted a study on the viability of various socalled green harvesting techniques. Its research and oversight of the Green Cane Harvesting Project were motivated by the now closed Sugar Area Development Programme intended to help cane workers displaced by the decline in production as well as the roll-out of the revised Jamaica Country Strategy, which included a series of national environmental goals (Ministry of Industry, Commerce, Agriculture and Fisheries 2018). The study tested both mechanized and semimechanized recovery of trash from farms located in St. Catherine and Clarendon and found the practices to be uneconomical in the industry's current state. Challenges caused by harvester efficiency, field conditions, and cane variety drove costs up to $\$ 500$ per tonne of trash recovered. Though less expensive when left behind in the field, the vast surface area of trash tampers with 
the effectiveness of certain irrigation practices and contributes methane emissions upon decomposition. Whole-cane harvesting is another option that warrants further research.

Sugar Production: Producing raw sugar from sugarcane entails crushing the stalks, filtering the resultant cane juice, and crystalizing the final product. The process outputs an array of byproducts, including molasses, bagasse, and filter cake that may be reincorporated either into the agricultural or production phases of sugar and biofuels production.

Fermentation: Though similar to those used for rum, commercial-scale fermentation facilities for ethanol do not exist in Jamaica. Several pilots attempted to revive the practice since the closure of the Bernard Lodge facility, but none has since taken hold.

Dehydration: Though there are operable dehydration facilities in Jamaica, they are not currently in use. PEL owns one facility, but it is closed due to the prohibitive cost of hydrous ethanol without intent to reopen in the foreseeable future. To fulfill the current E10 mandate, Jamaica imports denatured anhydrous ethanol from New York (Petrojam 2019).

Programs, aid, and ongoing research: Farmers seeking financial assistance can apply for a loan or grant from the Cane Expansion Fund. The fund caters to those with an expressed need related to cane planting and replanting, land clearing, drip irrigation, land preparation, and farm equipment (SIA 2017). To apply for these resources, farmers must first qualify under the standards set forth in the loan requirements. Repayment occurs through regular deductions from revenue over the course of five to seven years - sometimes longer (MAF 2016). Occasionally difficult seasons will incur a pause in collections, but this relief for current loan recipients reduces the funding available to farmers the following year (SIA 2017). If a farmer wishes to import new equipment from abroad, they must front the costs themselves and apply for refinancing from the $\mathrm{CEF}$ at a later time. Presently, the equipment loans are reserved for the procurement of used materials that are already available domestically (SIA 2017). This makes it difficult for farms to procure machinery with greater efficiency.

\section{Key Assumptions and Parameters}

Taking the current ethanol production practices into account as much as the Greenhouse Gases, Regulated Emissions, and Energy Use in Transportation (GREET) model will allow, we developed key assumptions and parameters to help determine the GHG emissions of Jamaican sugarcane ethanol. The sugarcane crop cycle varies by local climate, varieties, crop management, and resource (e.g., water) availability, among other factors. In Jamaica, the recommended duration of the cane cycle is 7 years (plant cane and 6 ratoons though the average cycle could be longer or shorter than 7 years). Payback is usually at the third year but could be sooner or later based on inputs (Bandy 2019).

During sugarcane production, a number of field operations generate GHG emissions. Previous LCA on sugarcane production suggests that fuel consumption for farming activities (e.g., planting/replanting, harvesting); use of agricultural chemicals, including fertilizer (such as nitrogen or $\mathrm{N}$ fertilizer), herbicide, and limestone; filter cake application (residue from sugarcane juice filtration); and pre-harvest burning of straw (e.g., illicit fires in cane fields) are the key sources of GHG emissions. Hauling sugarcane stalks to processing facilities also emits GHGs. Typically, carbon dioxide $\left(\mathrm{CO}_{2}\right)$, nitrous oxide $\left(\mathrm{N}_{2} \mathrm{O}\right)$, and methane $\left(\mathrm{CH}_{4}\right)$ are the three GHGs 
estimated and reported in the lifecycle studies for sugarcane and ethanol production. By definition, LCA takes into account GHG emissions associated with the upstream activities of direct inputs per the guidelines of ISO14040 and ISO14044 for LCA. For example, diesel fuel is used to power agricultural equipment. In addition to the direct emissions when diesel fuel is burned to power machinery, any emissions associated with crude oil extraction, crude oil refining, and diesel fuel transportation and distribution to deliver the diesel fuel for use in agricultural machinery are accounted for in the LCA.

Although a breakdown of fuel consumption by farming operations (e.g., plant cane, ratoon, harvesting, loading) is not available for sugarcane production in Jamaica, some information on cane harvesting was provided based on three field measurements, which indicate diesel fuel use ranges from 2.88 to $4 \mathrm{~L} /$ tonne cane (tc). The variations in fuel use are attributable to differences in equipment age and conditions as well as sugarcane density. Old and inefficient harvesters along with low density at two measurement fields lead to higher fuel consumption (3.58 and $4 \mathrm{~L} / \mathrm{tc}$ ), respectively) as compared to an internationally acceptable standard of fuel consumption at $2 \mathrm{~L} / \mathrm{tc}$ for mechanical harvesting of sugarcane. Operational performance of agricultural equipment is expected to improve in the future, and statistical data on fuel consumption could be gathered from future field operations. For a comparison, cane harvesting, loading, and in-field hauling/transloading in Brazil consumed an average 1.6 L of diesel fuel per tonne of cane harvested in the 2005-2006 season (Macedo et al. 2008). We use the average of the three field measurements $(3.5 \mathrm{~L} / \mathrm{tc})$ for the base case LCA, with an upper bound of $4 \mathrm{~L} / \mathrm{tc}$ (the highest among the three Jamaican measurements) and a lower bound of 1.6L/tc (Brazilian average) for the sensitivity analysis.

Because of a lack of credible data for cane planting and ratoon in Jamaica, we use Brazilian data as a proxy; we assume $103 \mathrm{~L}$ of diesel are required for each hectare of cane planting and $9 \mathrm{~L}$ of diesel for each ratoon based on Macedo et al. (2008) as a lower bound estimate. We assume an upper bound diesel consumption for cane planting and ratoon using data on the expanded sugarcane production in south-central Brazil during 2006 and 2011. It was estimated that $167 \mathrm{~L}$ of diesel were consumed to plant one hectare of cane and $16 \mathrm{~L}$ for each ratoon maintenance when pre-harvest burning was used (Bordonal 2016). The average of upper and lower bounds is assumed for the base case estimate, assuming a sugarcane yield of 55 tonnes per hectare (i.e., the average yield over the last decade in Jamaica). Although farms highly depend on rainfall to meet the water requirement by sugarcane plants, some sugarcane fields are irrigated during drought months or drought years. No data is available on the percentage of sugarcane fields receiving irrigation during normal and drought years, the amount of irrigation water used if irrigation is employed, and energy (e.g., diesel) required to pump irrigation water to the fields. Because of the lack of data, our assumed upper bound energy consumption for sugarcane production in Jamaica could have underestimated fuel consumption under certain circumstances.

Application of fertilizers (nitrogen fertilizer, in particular) is another primary GHG emission source during sugarcane production. Fertilizer is recommended to be applied after a soil test is done. In the absence of a soil test, farmers generally apply 12.5 bags per hectare $(1 \mathrm{bag}=50 \mathrm{~kg})$ based on estimates provided by All-Island Cane Farmers Association 2018. The standard blends are: 14-28-14 for plant cane, 16-9-18, 17-0-17, and 17-0-20 for ratoons. Urea and sulphate of ammonia are sometimes used as side-dressings. Given a lack of farm- or site-specific information on the amount of fertilizers applied to cane planting and ratoons, we assume each 
hectare receives 12.5 bags of 14-28-14 for cane planting (i.e., $87.5 \mathrm{~kg} \mathrm{~N}, 175 \mathrm{~kg} \mathrm{P}_{2} \mathrm{O}_{5}$, and 87.5 $\mathrm{kg} \mathrm{K}_{2} \mathrm{O}$ ) and 4.17 bags of 16-9-18, 17-0-17 and 17-0-20 each (i.e., $104.2 \mathrm{~kg} \mathrm{~N}, 18.8 \mathrm{~kg}_{2} \mathrm{O}_{5}$, and $114.6 \mathrm{~kg} \mathrm{~K}_{2} \mathrm{O}$ ) for each of the subsequent ratoons per the rule of thumb. At an average sugarcane yield of $55 \mathrm{tc} / \mathrm{ha}$, the respective $\mathrm{N}, \mathrm{P}_{2} \mathrm{O}_{5}$, and $\mathrm{K}_{2} \mathrm{O}$ requirements of $1.86,0.75,2.01 \mathrm{~kg} / \mathrm{tc}$ are used for the base case estimate. However, applying $\mathrm{P}$ and $\mathrm{K}$ fertilizers to the field does not result in direct GHG emissions, though the upstream manufacturing processes result in GHG emissions. As a reference, synthetic $\mathrm{N}, \mathrm{P}_{2} \mathrm{O}_{5}$, and $\mathrm{K}_{2} \mathrm{O}$ inputs for Brazilian sugarcane are typically in the range of 0.72 to $0.88,0.27$ to 0.33 , and 0.9 to $1.1 \mathrm{~kg} / \mathrm{tc}$, respectively. We assume an input of 0.72 $\mathrm{kg}$ synthetic $\mathrm{N}$ per tonne of cane for a lower bound estimate in the sensitivity analysis.

It should be noted that applying residues such as filter cake (which contains $\mathrm{N}$ ) and leaving biomass such as straw in the field also emit $\mathrm{N}_{2} \mathrm{O}$ emission. Macedo et al. (2008) estimates that after juice treatment, 6 to $8 \mathrm{~kg}$ (dry basis) of filter cake are produced for each tonne of cane processed. Farmers typically apply filter cake to the sugarcane field to supplement synthetic N fertilizer. While data are not available for Jamaican sugarcane production, we assume an average $2.9 \mathrm{~kg}$ filter cake (per tonne cane processed) are returned to the sugarcane fields as nutrients in the base case analysis based on Cai et al. (2012). For the sensitivity analysis, we assume a range between 0 and $4 \mathrm{~kg}$ filter cake are utilized as $\mathrm{N}$ nutrients. The nitrogen contents in filter cake and straw are taken from Macedo et al. (2008). Per IPCC (2006), it is estimated that $1.225 \%$ of $\mathrm{N}$ in residue is converted to $\mathrm{N}$ in $\mathrm{N}_{2} \mathrm{O}$ emissions.

Synthetic $\mathrm{N}$ fertilizers containing ammonium-N are one of the primary reasons for the acidity in soil to increase gradually when the ammonium-N undergoes nitrification (i.e., conversion of ammonium to nitrate by bacteria) and hydrogen $\left(\mathrm{H}^{+}\right)$is released. Existing lifecycle studies on Brazilian sugarcane ethanol report a range of 4.7 to $5.7 \mathrm{~kg} / \mathrm{tc}$ of lime inputs (Cai et al. 2012). It is unclear how much of $\mathrm{N}$ fertilizers applied to sugarcane fields in Jamaica are ammonium-N. Given the lack of Jamaica-specific data on lime usage during sugarcane production, we assume no lime use in the base case analysis. However, this assumption likely leads to the underestimation of lifecycle GHG emissions because 1) some lime is likely needed to maintain soil $\mathrm{pH}$ within an acceptable range, and 2) agricultural liming is a non-trivial source of $\mathrm{CO}_{2}$ emissions (e.g., $0.48 \mathrm{~kg}$ of $\mathrm{CO}_{2}$ are estimated to be emitted for 1 $\mathrm{kg}$ of dolomite lime applied (IPCC 2006)). For the sensitivity analysis, we assume a lime input of $5.7 \mathrm{~kg} / \mathrm{tc}$ per Cai et al. (2012).

A wide variety of chemicals is used to control weeds depending on the types of weeds in a particular sugarcane field. The two most commonly used herbicides in Jamaica are Terbutryn and Diuron (All-Island Cane Farmers Association 2018). Herbicide inputs depend on weather (e.g., abundant precipitation appears to stimulate persistent weed growth despite weed controls) and other factors (e.g., availability of funds) (All-Island Cane Farmers Association 2018). Statistics on herbicides use are unavailable. Macedo et al. (2008) suggests an average herbicide requirement of $2.2 \mathrm{~kg} / \mathrm{ha}$ for sugarcane production in Brazil. We assume this application rate is applicable to Jamaican sugarcane production.

Historical statistics on pre-harvest field burning are not available for Jamaican sugarcane production at a national level. It is estimated that about $95 \%$ of sugarcane acreage is harvested via pre-harvest burning while the remaining 5\% is green harvested (All-Island Jamaica Cane Farmer's Association 2019). Burning straw leads to the generation of large amounts of 
various air pollutants, including $\mathrm{CO}_{2}$, particulate matter, $\mathrm{NO}_{\mathrm{x}}, \mathrm{N}_{2} \mathrm{O}, \mathrm{CH}_{4}$, and hydrocarbon emissions. Because $\mathrm{CO}_{2}$ emissions from straw burning are considered biogenic (i.e., carbon taken from the air during sugarcane growth), we only account for $\mathrm{CH}_{4}$ and $\mathrm{N}_{2} \mathrm{O}$ emissions from straw burning in the GHG analysis. The straw yield is approximately 0.14 dry tonnes for each tonne of sugarcane (Cai et al. 2012). Burning one dry tonne of straw is estimated to emit about $83 \mathrm{~kg}$ of $\mathrm{CO}_{2}$ eq. of $\mathrm{GHG}$ emissions $\left(21 \mathrm{~kg} \mathrm{~N}_{2} \mathrm{O}\right.$ and $62 \mathrm{~kg} \mathrm{CH}_{4}$, all in $\mathrm{CO}_{2}$ ).

Practices used to harvest sugarcane have been evolving due to various factors such as economic considerations and environmental protocols (e.g., green cane production). Manual cutting and mechanical harvesting are expected to continue to co-exist in the near future. However, it is likely more farmers/estates may adopt green cane harvesting to reduce pre-harvest burning of straw in the field in the future. While harvesting green is a preferred practice from an environmental perspective, it is not always practical under certain less than ideal topography and field conditions (e.g., very wet soil) and could have economic tradeoffs as well. To show how reducing pre-harvesting burning may reduce GHG emissions, the sensitivity analysis assumes an optimal $100 \%$ green cane harvest scenario, where no sugarcane field is burned before harvesting, as the lower bound for the GHG estimates. Because of many illicit pre-harvesting burns as indicated in the All-Island Cane Association 2018 report, we assume a 100\% pre-harvesting burning as the upper bound for the GHG estimates.

Once the sugarcane is harvested, we assume it is transported to the sugarcane ethanol facilities by truck. Given that no sugarcane ethanol facility exists currently, we assume an average transportation distance of $20 \mathrm{~km}$ for sugarcane transportation from the sugarcane farms to the ethanol plants. Macedo et al. (2008) noted a recent logistics trend, which is replacing the single load trucks with high capacity trucks in Brazil. However, there could be regulations that restrict the load capacity for cane transportation. For our analysis, we assume a single load truck with an average load capacity of 17 tonne.

The sugarcane ethanol process begins with cane cleaning and crushing to produce juice, which contains sucrose readily broken down into glucose and fructose during fermentation by enzymes to produce wine. The wine is then distillated to produce hydrous ethanol, which may be stored as a final product or dehydrated to produce anhydrous ethanol. After the juice is extracted from the sugarcane stalk, the bagasse is typically used to produce heat and power for the conversion process.

Ethanol production from sugarcane is a mature and relatively simple technology compared to ethanol production from starch (e.g., corn). We assume the current state of the art of ethanol conversion is achievable if new facilities are built to produce ethanol from sugarcane in the near future in Jamaica. Ethanol yield (i.e., amount of ethanol produced from each tonne of sugarcane processed) is dependent on the sucrose content, which varies by variety, maturity, and harvest time, and the efficiency in converting sucrose to ethanol. The current average yield of sugarcane ethanol is about $80 \mathrm{~L} /$ tc processed. Macedo et al. (2008) indicate that the industry's efficiency in utilizing sucrose is about $90 \%$ at present, and no significant improvement is expected in the near term. For the sensitivity analysis, we assume a range of ethanol yield between 73 and $89 \mathrm{~L} /$ tonne per Cai et al. (2012). 
Many sugarcane ethanol facilities in Brazil produce a small amount of excess electricity (after meeting their own demand) from using the bagasse, which is exported to the grid. Newer sugarcane plants in Brazil are often equipped with more efficient steam and power generation systems and use both bagasse and sugarcane straw (harvested along with sugarcane) to generate process energy (steam and electricity) and could export more electricity to the grid.

Given that sugarcane ethanol is not currently produced in Jamaica, we assume that ethanol plants built in the future (or expanded from existing sugar mills) will be energy-sufficient by using bagasse to produce steam and electricity required for their operations. About 0.28 tonne of bagasse are generated from processing each tonne of sugarcane, which is used as the fuel to produce energy on-site. It is unclear whether ethanol facilities will be able to sell any excess electricity to the grid because regulations may restrict sale of electricity by non-utility generators. For the GHG analysis, we assume no electricity will be exported to the grid to replace existing generation.

The plants are expected to need a small amount of fossil fuels for equipment such as forklifts and lubricants (about $0.16 \mathrm{~L}$ residual oil/tc) and various chemicals (e.g., sulfuric acid, lime, antifoam) for use in sugarcane processing. Macedo et al. (2008) estimated that the ethanol conversion process generates about $2.2 \mathrm{~kg}$ of $\mathrm{CO}_{2}$ eq for each tonne of cane processed. The ethanol facilities also produce two other by-products from the conversion process, which are filter cake (discussed earlier) and vinasse (generated from the ethanol distillation operations). Vinasse can be used as a soil amendment or a livestock feed. For the GHG analysis, we assume vinasse will be used as a livestock feed.

Because the locations of potential sugarcane ethanol facilities are unknown, we assume the finished ethanol will be transported by heavy-duty trucks to the terminals for approximately 10 $\mathrm{km}$ (a $20-\mathrm{km}$ round trip) and then another $5 \mathrm{~km}$ to the refueling station. Because carbon in ethanol is considered biogenic (i.e., taken up from the air during sugarcane growth), GHG emissions from fuel ethanol combustion in vehicles are negligible.

Using the data described above, the lifecycle GHG emissions for ethanol produced from locally grown sugarcane in Jamaica is estimated at $635 \mathrm{~g} \mathrm{CO}_{2} \mathrm{eq} / \mathrm{L}$ or $\sim 29 \mathrm{~g} \mathrm{CO}_{2} / \mathrm{MJ}$ of ethanol under the base case assumptions. For comparison, the estimated lifecycle GHG of ethanol produced and consumed in the United States ranges from 41 to $67 \mathrm{~g} \mathrm{CO}_{2} / \mathrm{MJ}$, depending on the agricultural practices for corn farming and the type of fuel used in corn conversion to ethanol, as well as other factors. Note that the lifecycle GHG estimates do not include emissions from so-called land use change (both domestic and international).

In addition to the base case scenario, our sensitivity analysis indicates that synthetic nitrogen fertilizer consumption, pre-harvesting burning, and diesel use for cane harvesting are the three key factors that affect the GHG intensity of sugarcane production. With the potential adoption of more sustainable agricultural practices, the GHG intensity of sugarcane production could be further reduced. For example, eliminating pre-harvest burning alone could reduce GHG emissions by about $25 \%$ for sugarcane production (i.e., a reduction of $11.6 \mathrm{~kg} \mathrm{CO}_{2}$ eq. for each tonne of cane). 
Given that Jamaica currently imports corn ethanol from the United States and that corn ethanol has a higher lifecycle GHG intensity than that of sugarcane ethanol, switching to domestically produced ethanol is expected to result in GHG reduction. Under our base case scenario, the switch is estimated to yield a GHG reduction of $29 \%$ to $57 \%$ for each liter of ethanol displaced. Higher GHG reduction benefits are feasible if Jamaica elects to adopt more sustainable sugarcane production practices.

Table 7. Key Assumptions Associated with Sugarcane Production, Transportation, and Conversion.

\begin{tabular}{|c|c|c|c|}
\hline \multicolumn{4}{|l|}{ Sugarcane production } \\
\hline Parameters/assumptions & Base case & Upper bound & Lower bound \\
\hline $\begin{array}{l}\text { Diesel use for cane planting } \\
\text { and ratoon } \\
\text { (L/tc) }\end{array}$ & 0.55 & 0.68 & 0.41 \\
\hline Diesel use for harvesting (L/tc) & 3.5 & 4.0 & 1.6 \\
\hline Nitrogen fertilizer $(\mathrm{kg} / \mathrm{tc})$ & 1.86 & 1.86 & 0.72 \\
\hline $\begin{array}{l}\mathrm{P}_{2} \mathrm{O}_{5} \text { fertilizer } \\
(\mathrm{kg} / \mathrm{tc})\end{array}$ & 0.75 & na & na \\
\hline $\begin{array}{l}\mathrm{K}_{2} \mathrm{O} \text { fertilizer } \\
(\mathrm{kg} / \mathrm{tc})\end{array}$ & 2.0 & na & na \\
\hline $\begin{array}{l}\text { Limestone }\left(\mathrm{CaCO}_{3}\right) \\
(\mathrm{kg} / \mathrm{tc})\end{array}$ & 0 & 5.7 & $\begin{array}{l}\text { Same as base } \\
\text { case }\end{array}$ \\
\hline Pesticide & 40 & na & na \\
\hline $\begin{array}{l}\text { Pre-harvest burning of } \\
\text { sugarcane fields (\% among } \\
\text { total sugarcane fields } \\
\text { harvested) }\end{array}$ & $95 \%$ & $100 \%$ & 0 \\
\hline $\begin{array}{l}\text { Filter cake returned to the field } \\
\text { after processing sugarcane } \\
(\mathrm{kg} / \mathrm{tc})\end{array}$ & 2.9 & 4.0 & 0 \\
\hline \multicolumn{4}{|l|}{ Sugarcane transportation } \\
\hline $\begin{array}{l}\text { Distance to ethanol facilities } \\
(\mathrm{km})\end{array}$ & 20 & 50 & 10 \\
\hline Truck load capacity (tonne) & 17 & na & $\mathrm{ma}$ \\
\hline Fuel economy (kg/L of diesel) & $\begin{array}{l}3.5 \text { (at full load) } \\
3.8 \text { (empty, } \\
\text { e.g., back from } \\
\text { product } \\
\text { destination) }\end{array}$ & na & na \\
\hline \multicolumn{4}{|l|}{ Sugarcane production } \\
\hline Ethanol yield $(\mathrm{L} / \mathrm{tc})$ & 80 & 89 & 73 \\
\hline Fossil energy use (L/tc) & 0.16 & na & na \\
\hline \multicolumn{4}{|c|}{ Ethanol transportation and distribution } \\
\hline $\begin{array}{c}\text { Transportation from ethanol } \\
\text { plants to terminal }(\mathrm{km})\end{array}$ & 10 & na & na \\
\hline $\begin{array}{l}\text { Transportation from ethanol } \\
\text { plants to terminal }(\mathrm{km})\end{array}$ & 5 & na & na \\
\hline
\end{tabular}




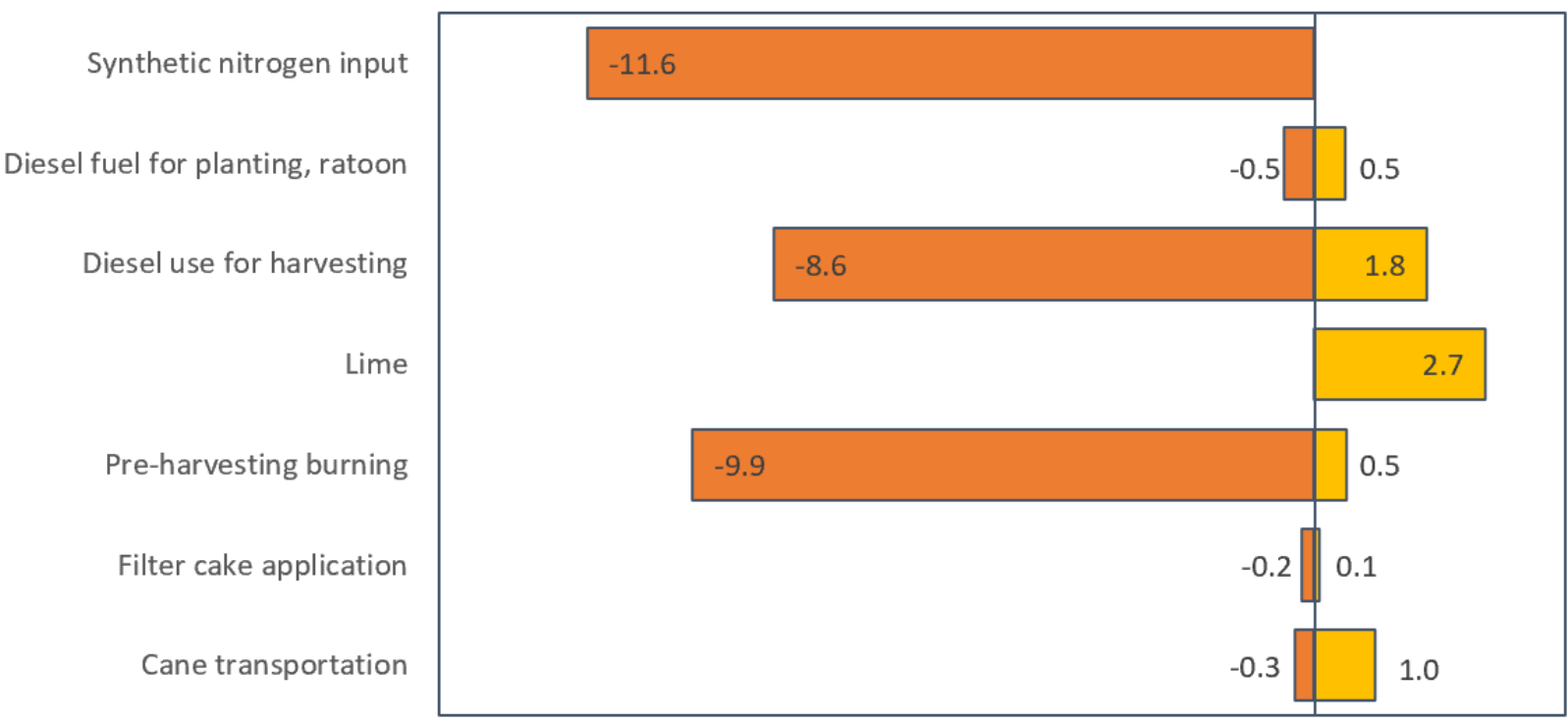

Figure 4. Impacts of selected operations on lifecycle $\mathrm{GHG}\left(\mathrm{g} \mathrm{CO}_{2} \mathrm{eq} /\right.$ tonne of cane delivered) Note: the middle line represents the base case GHG emissions of sugarcane production at $46.9 \mathrm{~kg} \mathrm{CO} 2$ eq/tonne of cane delivered)

\section{Economic Impacts of Domestic Ethanol Production}

Jamaica is currently sending large sums of money out of its domestic economy to purchase foreign gasoline, crude oil, and ethanol. By displacing foreign petroleum and ethanol with domestic ethanol, Jamaica should be able to bring some of these expenditures back into its domestic economy, where they can be recirculated to boost GDP. However, a domestic ethanol industry also requires foreign equipment expenditures that need to be accounted for.

Jamaica's transition to domestic ethanol production would require significant investment in production capacity and facility operations, agricultural resource capacity, logistics infrastructure, fueling station infrastructure, and vehicle fleet conversion. This section estimates the key outgoing costs for fuel today and compares them to the investments that would need to be made to produce ethanol domestically. Table 8 shows the net decrease in foreign expenditures when switching from imported petroleum and corn-based ethanol, with explanations in the section below. The net decrease in foreign expenditures is money that remains in Jamaica's economy to recirculate and increase its GDP.

Table 8. Net Decrease in Foreign Expenditures Derived from Domestic Sugarcane Ethanol (mil USD)

\begin{tabular}{|l|c|c|c|c|c|c|}
\hline Target Year & \multicolumn{2}{|c|}{2030} & \multicolumn{3}{c|}{2050} \\
\hline Fuel Blend & $\mathrm{E} 10$ & $\mathrm{E} 15$ & $\mathrm{E} 25$ & $\mathrm{E} 10$ & $\mathrm{E} 15$ & E25 \\
\hline $\begin{array}{l}\text { Foreign fuel expenditures under E10 } \\
\text { business-as-usual scenario }\end{array}$ & $\$ 751$ & $\$ 751$ & $\$ 751$ & $\$ 1,620$ & $\$ 1,620$ & $\$ 1,620$ \\
\hline $\begin{array}{l}\text { Foreign gasoline expenditures with domestic } \\
\text { ethanol production }\end{array}$ & $\$ 675$ & $\$ 638$ & $\$ 563$ & $\$ 1,478$ & $\$ 1,396$ & $\$ 1,232$ \\
\hline Production facility capital costs* & $\$ 3.3$ & $\$ 5.0$ & $\$ 8.2$ & $\$ 4.2$ & $\$ 6.2$ & $\$ 10.5$ \\
\hline
\end{tabular}




\begin{tabular}{|l|c|c|c|c|c|c|}
\hline Target Year & \multicolumn{3}{|c|}{2030} & \multicolumn{3}{c|}{2050} \\
\hline $\begin{array}{l}\text { Farming costs (fuel, fertilizer, pesticides, } \\
\text { machinery) }\end{array}$ & $\$ 7.5$ & $\$ 11.2$ & $\$ 18.7$ & $\$ 9.5$ & $\$ 14.2$ & $\$ 23.7$ \\
\hline $\begin{array}{l}\text { Biorefinery operating costs - fuels and } \\
\text { materials }\end{array}$ & $\$ 5.1$ & $\$ 7.7$ & $\$ 12.8$ & $\$ 6.5$ & $\$ 9.7$ & $\$ 16.2$ \\
\hline Fuel station preparation & $\$ 0.0$ & $\$ 0.3$ & $\$ 0.3$ & $\$ 0.0$ & $\$ 0.0$ & $\$ 0.0$ \\
\hline Vehicle incremental cost & $\$ 0.0$ & $\$ 0.0$ & $\$ 10.1$ & $\$ 0.0$ & $\$ 0.0$ & $\$ 6.7$ \\
\hline Net decrease in foreign expenditures & $\$ 59.6$ & $\$ 88.8$ & $\$ 138.0$ & $\$ 121.7$ & $\$ 193.8$ & $\$ 331.2$ \\
\hline
\end{tabular}

${ }^{*}$ Amortized over 30 years (facility life)

\section{Costs of Foreign Fuel Purchases}

Jamaica currently purchases nearly all of its transportation fuel (gasoline, crude oil, and ethanol) from international markets (MSET 2019c). In order to estimate the amount of money this transfers out of the Jamaican economy, we need to start with the amount of E10 Jamaica is estimated to use, as shown in Table 9.

Table 9. Projected E10 Consumption in Jamaica

\begin{tabular}{|c|c|}
\hline Year & Million Liters E10 \\
\hline 2017 & 711 \\
\hline 2019 & 735 \\
\hline 2030 & 838 \\
\hline 2050 & 1,063 \\
\hline
\end{tabular}

Source: Johnson et al. 2019

To convert from the projected fuel consumption to the associated foreign expenditures requires a number of conversion factors and assumptions. First, we assume that Jamaica refines $41 \%$ of its gasoline from imported crude oil and imports the remaining 59\% as refined gasoline. This matches the ratios of non-bauxite related petroleum product usage in Jamaica in 2018 (MSET 2019c). We then assume that the foreign gasoline purchases follow the wholesale price projections laid out in EIA (2019b), discounted 23\% to match Gulf Coast Spot Prices, which have been an average of $23 \%$ less than wholesale for the past decade (EIA 2019c). The foreign expenditures on gasoline refined in Jamaica are the wholesale price of gasoline, minus the refinery margin (which is money assumed to stay in the Jamaican economy). The refinery margin is assumed to be $\$ 0.03 / \mathrm{L}$ based on McKinsey 2019. The price of ethanol is set to match the wholesale ethanol price projections in EIA's Annual Energy Outlook 2019. Finally, it is assumed that E15 and E25 can achieve comparable volumetric fuel economy to E10, despite its lower energy density, because its higher octane enables more efficient engine design. This implies a 4\% efficiency improvement for E25, which is the goal of engine manufacturers and has been achieved in field studies (West 2017; McCormick 2016). When costs are applied in their proper ratios, it allows us to estimate the amount of money that would be exported from Jamaica's economy if E10, E15, or E25 with no domestic ethanol production, as shown in Table 10 . 
Table 10. Projected Amount Spent Fuel Imported to Jamaica, If No Domestic Ethanol Production (2018 USD, mil)

\begin{tabular}{|l|l|l|l|}
\hline Year & E10 & E15 & E25 \\
\hline 2017 & $\$ 293$ & na & na \\
\hline 2019 & $\$ 426$ & $\$ 419$ & $\$ 407$ \\
\hline 2030 & $\$ 751$ & $\$ 751$ & $\$ 751$ \\
\hline 2050 & $\$ 1,620$ & $\$ 1,609$ & $\$ 1,587$ \\
\hline
\end{tabular}

See text above table for assumptions and sources

\section{Ethanol Production Costs}

\section{Biorefinery Capital Costs}

The scale of the investment in ethanol production capacity is driven by the volume of ethanol needed to meet domestic ethanol demand. Although it could be possible to increase capacity beyond domestic needs to allow for export, the scope of this report is limited to domestic demand; in addition, as indicated by the production pathways presented in the "Ethanol Potential" section above, it will be challenging enough for Jamaica to produce sufficient sugarcane feedstock to meet upper-end domestic demands (i.e., E25 in 2050), let alone export needs. Table 4 provides estimated volumes of ethanol needed in E10, E15, and E25 through 2050. Figure 5 shows the estimated capital costs for distilleries sized to produce the specified volumes of ethanol.

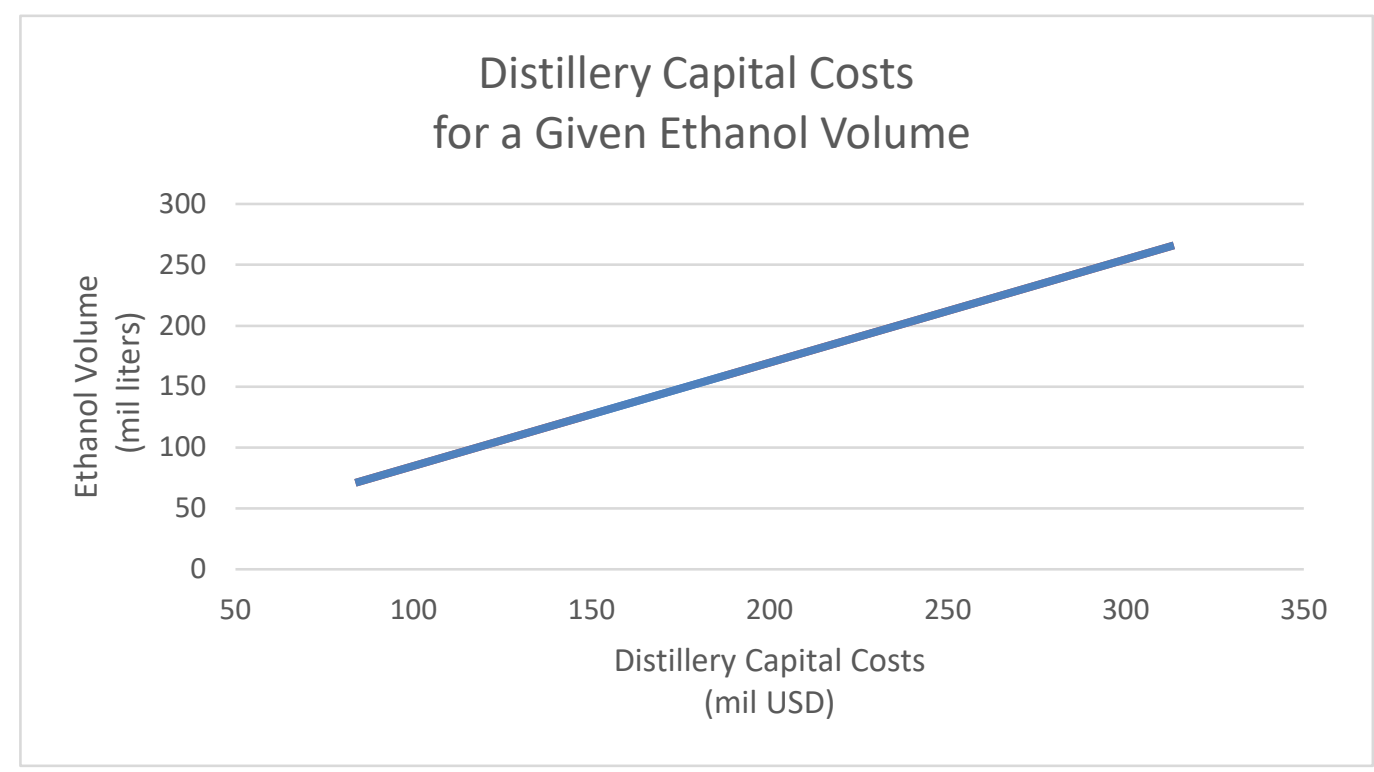

Figure 5. Estimated capital costs for biorefineries required to meet domestic demand

The capital costs for ethanol production facilities reflected in Figure 5 use an average cost of $\$ 1.18 / \mathrm{L}$, which is derived from a number of sources that look at facilities in a range of countries, so should be considered as initial estimates only (Klein et al. 2019; Cortez et al. 2019; Wang et 
al. 2018). The facility costs in this estimate include design, equipment, and construction, which are assumed to be sourced from a foreign firm. They do not include the cost of financing due to the range of potential financing mechanisms, including concessional loans from international development banks. This estimate assumes a linear cost per liter, so does not consider potential cost savings for increasing facility size. Actual costs will depend on various factors, including facility sizes, financing terms, proximity to cane sources, labor costs, land costs, local material costs, and import taxes.

The capital costs in Figure 5 are for projects with a 30-year lifespan, sized to meet the anticipated annual ethanol production needs for the given year. For example, the expected demand for ethanol in 2030 under an E15 policy scenario is 126 million liters per year, as shown in Table 4, which would require a plant that costs approximately $\$ 149$ million. This cost would be spread out over a number of years based on the terms of the financing mechanism used, over which time the facility would continue to produce 126 million liters annually. There are a number of approaches Jamaica could take for scaling and sequencing construction of production capacity. For example, it would be appropriate to coordinate implementation of any ethanol mandates with investment strategies to ramp up domestic production over time with medium-size plants that can meet mid-term demands instead of immediate investments in large facilities that may sit idle until demand materializes.

Typical plant sizes for markets similar to Jamaica's range from 55 to 225 million liters per year, but engineering firms can offer customized sizes and designs. Further, larger plant sizes can generally be built at lower costs. These factors, along with anticipated demand growth, should be carefully considered when determining the optimal sequencing and size mix for investment in facility construction.

The production process consists of three general steps: sugar extraction from the cane, sugar fermentation to generate ethanol, and ethanol separation and purification. Facilities can be designed to sell excess power to the grid in the form of electricity, with a trade-off between installation costs and revenue from electricity sales. The analysis here does not consider the sale of excess electricity. The primary components of an ethanol production facility to perform these steps are depicted in Figure 6.

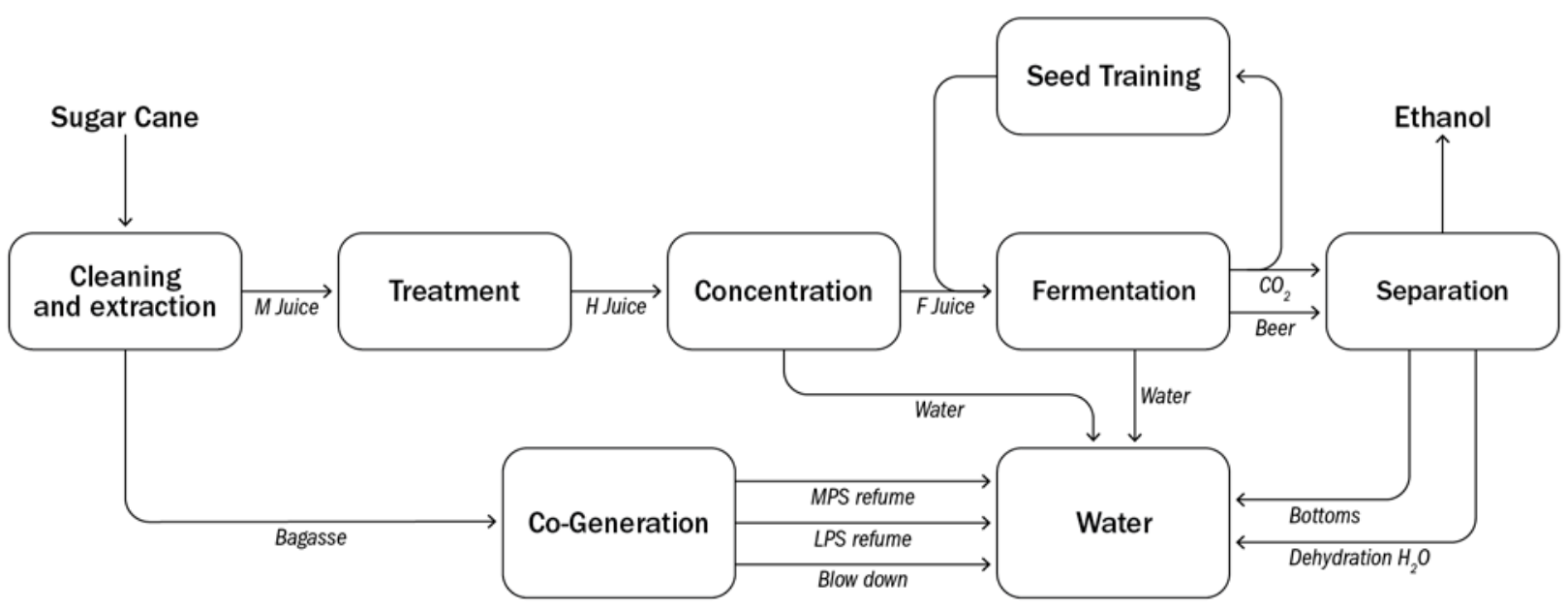

Figure 6. Primary components of a typical ethanol production facility 
With Jamaica's history of interest and investment in ethanol production and dehydration facilities, there is the potential that currently shuttered facilities and equipment could be revitalized and used in new ethanol production. Though no fermentation facilities exist in Jamaica, PEL's 40-million-gallon dehydration tank remains functional, albeit unused and unmaintained (Jamaica Information Service 2015). This report does not explore the viability and savings available through use of existing equipment, but the value of equipment and lessons learned from previous related efforts should not be ignored, and should be further investigated.

\section{Ongoing Operating and Sugarcane Farming Costs}

Ongoing operating costs for ethanol production facilities include materials and labor and energy, but are dominated by the cost of sugarcane. Several studies of Brazilian sugarcane ethanol production indicate that roughly $70 \%$ of annual operating expenditures go to cane supply, around $18 \%$ go to fuels and materials, and the remaining $12 \%$ to labor and maintenance (Tao and Aden 2009; Asia Pacific Economic Cooperation 2010; Macrelli and Zacchi 2012). We use this cost breakdown to provide broad estimates for annual operating costs. However, it should be noted that given the differences in industry maturity and growing conditions between Jamaica and Brazil, the estimates represent only benchmarks for a new Jamaican ethanol industry.

To do this, we have taken into consideration the relative sugarcane productivity (tonnes per hectare) in Brazil and Jamaica to scale the cost of sugarcane upward, and added that cost to the costs for fuels, materials, labor, and maintenance in Brazil to estimate operational costs in Jamaica. Assuming Jamaican cane productivity is $68 \%$ of Brazil's (which is consistently over 70 $\mathrm{t} /$ ha [OAS 2011]), the resulting estimated cost of the sugarcane portion is $\$ 0.35 /$ iter of ethanol while the total cost of ethanol production is estimated to be $\$ 0.44 /$ liter. This can be compared to production costs of \$0.34/liter in Brazil (Tao and Aden 2009).

Table 11 highlights the annual operating cost estimates compared to the estimated ethanol volume requirements from Table 4 . These costs include fuels, materials, labor, and maintenance, but do not include sugarcane feedstock, which we include in farming costs below.

Table 11. Estimated Annual Operating Costs for Ethanol Production

\begin{tabular}{|c|c|c|c|c|c|c|}
\hline \multirow{2}{*}{ Year } & \multicolumn{2}{|c|}{ E10 } & \multicolumn{2}{c|}{ E15 } & \multicolumn{2}{c|}{ E25 } \\
\cline { 2 - 7 } & $\begin{array}{c}\text { Ethanol } \\
\text { Volume } \\
\text { (mil liters) }\end{array}$ & $\begin{array}{c}\text { Operating } \\
\text { Costs } \\
\text { (USD, mil) }\end{array}$ & $\begin{array}{c}\text { Ethanol } \\
\text { Volume } \\
\text { (mil liters) }\end{array}$ & $\begin{array}{c}\text { Operating } \\
\text { Costs } \\
\text { (USD, mil) }\end{array}$ & $\begin{array}{c}\text { Ethanol } \\
\text { Volume } \\
\text { (mil liters) }\end{array}$ & $\begin{array}{c}\text { Operating } \\
\text { Costs } \\
\text { (USD, mil) }\end{array}$ \\
\hline 2017 & 71 & $\$ 6.8$ & 107 & $\$ 10.2$ & 178 & $\$ 17.0$ \\
\hline 2019 & 74 & $\$ 7.1$ & 110 & $\$ 10.5$ & 184 & $\$ 17.5$ \\
\hline 2030 & 84 & $\$ 8.0$ & 126 & $\$ 12.0$ & 210 & $\$ 20.0$ \\
\hline 2050 & 106 & $\$ 10.1$ & 159 & $\$ 15.2$ & 266 & $\$ 25.4$ \\
\hline
\end{tabular}

NREL estimates

Note that the results in Table 11 differ from those in Table 8, as Table 8 represents the portion of annual operating costs expected to leave the Jamaican economy. Those foreign expenditures include only costs for fuels and materials that must be imported. 
Further, we estimate the agriculture-related costs by assuming that cane purchasing costs are equal to the sum of profit, land rent, seed, fertilizer and other materials, labor, harvesting, and transportation costs associated with cane production. Table 12 shows the results, which include an estimate of the land area requirements based on ethanol volume estimates in Table 4 and a land productivity estimate of 3,850 L/ha (Li and Wei 2006).

Table 12. Estimated Annual Farming Costs for Ethanol Production

\begin{tabular}{|l|c|c|c|c|c|c|}
\hline & \multicolumn{2}{|c|}{ E10 } & \multicolumn{2}{c|}{ E15 } & \multicolumn{2}{c|}{ E25 } \\
\cline { 2 - 7 } & $\begin{array}{c}\text { Land } \\
\text { Required } \\
\text { (ha) }\end{array}$ & $\begin{array}{c}\text { Cane } \\
\text { Farming } \\
\text { Costs } \\
\text { Year }\end{array}$ & $\begin{array}{c}\text { Land } \\
\text { Required } \\
\text { (ha) }\end{array}$ & $\begin{array}{c}\text { Cane } \\
\text { Farming } \\
\text { Costs } \\
\text { (USD, mil) }\end{array}$ & $\begin{array}{c}\text { Land } \\
\text { Required } \\
\text { (ha) }\end{array}$ & $\begin{array}{c}\text { Cane } \\
\text { Farming } \\
\text { Costs } \\
\text { (USD, mil) }\end{array}$ \\
\hline 2017 & 16,136 & $\$ 24.8$ & 24,318 & $\$ 37.3$ & 40,455 & $\$ 62.1$ \\
\hline 2019 & 16,818 & $\$ 25.8$ & 25,000 & $\$ 38.4$ & 41,818 & $\$ 64.2$ \\
\hline 2030 & 19,091 & $\$ 29.3$ & 28,636 & $\$ 44.0$ & 47,727 & $\$ 73.3$ \\
\hline 2050 & 24,091 & $\$ 37.0$ & 36,136 & $\$ 55.5$ & 60,455 & $\$ 92.8$ \\
\hline
\end{tabular}

NREL estimates

Note that the land area requirements shown above differ from Table 5 because this table covers only ethanol cane requirements while Table 5 includes other non-ethanol needs. Further, as with the operating costs discussed above, the farming costs in Table 8 differ from Table 12 in that Table 8 includes only costs expected to leave the Jamaican economy, which we assume to cover fuel, fertilizer, pesticides, and machinery. Table 8 omits the costs of labor and land.

Although just over 18,000 ha contributed to the sugarcane supply in the 2017-2018 season (AllIsland Jamaica Cane Farmers Association 2018), the industry was once supported by almost 60,000 ha in the 1960s (SIA 2010). Assuming that some amount of this land remains available, scaling up agricultural production in the near term can be achieved with minimal land-use change. However, the ethanol demand that would result under an E25 mandate in the mid term would likely require expansion of agricultural lands and could introduce competition for food production.

\section{Costs of Equipping Fuel Stations}

If Jamaica pursues domestic E10, no upgrades need to be made to the fuel stations since they are already E10 compatible. However, some upgrades would be needed if higher blends are pursued, and these upgrades would require the purchase of foreign-made equipment. There are 128 active gasoline stations in Jamaica, ${ }^{2}$ and we assume that all of them will need to be equipped to sell higher blends of ethanol. Since most underground storage tanks are E15 and E25 compatible (United States Department of Energy 2016), and stations will not need to add a tank since the fuel will continue to be blended at the terminal, we assume that the tankage costs are zero. However, E15 and E25 should not be dispensed through older E10 dispensers. The industry does not make dedicated E15 dispensers. A station wishing to sell E15 needs to purchase a dispenser

${ }^{2}$ Google Maps search performed on April 28, 2019 
rated for E25. These dispensers are readily available in Jamaica, as nearly all of Wayne's dispensers are now E25-certified and Wayne has a substantial and growing market share in Jamaica (Negley 2019). New E25 dispensers are similar in price to their E10 counterparts (approximately $\$ 17,700$ [Moriarty et al. 2014]). However, a UL-listed retrofit kit only costs $\$ 2,100$, with an additional $\$ 835$ needed for hanging hardware and sheer valve. The average station in the United States is estimated to have three dispensers (Moriarty 2019), and it is assumed that Jamaica has the same average. In addition to dispenser costs, the tank should be cleaned at a cost of $\$ 1,500$ when increasing ethanol blend level. Therefore, it would cost the average station approximately $\$ 10,300$ to upgrade today.

However, most stations do not need to upgrade today. If they can wait for the end of the useful life of the dispenser, then they can simply replace their retired dispenser with an E25-compatible one, spending money that they would be spending anyway. The average dispenser life is 15 years (Moriarty et al. 2014), so any given year $1 / 15$ or $6.7 \%$ of dispensers will be replaced. Hanging hardware needs to be replaced every 3 years, so the $\$ 835$ should be avoidable as long as the implementation time is over 3 years. Therefore, when time is taken into consideration, the cost of equipping for E15 or E25 reduces as shown in Table 13. Note that this cost reduction only occurs if all equipment is replaced by E25-compatible equipment at the end of its useful life, starting in 2020. Ways to encourage this procurement practice will be discussed in the Policy Support section.

Table 13. Expenditures for E25/E15 Compatibility Decrease as Time Passes and More Equipment Reaches its Natural Expiration

\begin{tabular}{|c|c|c|c|c|c|}
\hline $\begin{array}{c}\text { Year E25- } \\
\text { Compatible }\end{array}$ & $\begin{array}{c}\text { Dispensers } \\
\text { Prematurely } \\
\text { Replaced }\end{array}$ & $\begin{array}{c}\text { Dispenser } \\
\text { Expenditure }\end{array}$ & $\begin{array}{c}\text { Hardware Sets } \\
\text { Prematurely } \\
\text { Replaced }\end{array}$ & $\begin{array}{c}\text { Total Foreign } \\
\text { Hardware } \\
\text { Expenditures }\end{array}$ & $\begin{array}{c}\text { Expenditures } \\
\text { on E15/E25 } \\
\text { Compatibility* }\end{array}$ \\
\hline 2020 & 384 & $\$ 806,400$ & 384 & $\$ 320,640$ & $\$ 1,127,040$ \\
\hline 2021 & 358 & $\$ 752,640$ & 256 & $\$ 213,760$ & $\$ 966,400$ \\
\hline 2022 & 333 & $\$ 698,880$ & 128 & $\$ 106,880$ & $\$ 805,760$ \\
\hline 2023 & 307 & $\$ 645,120$ & 0 & $\$ 0$ & $\$ 645,120$ \\
\hline 2024 & 282 & $\$ 591,360$ & 0 & $\$ 0$ & $\$ 591,360$ \\
\hline 2025 & 256 & $\$ 537,600$ & 0 & $\$ 0$ & $\$ 537,600$ \\
\hline 2026 & 230 & $\$ 483,840$ & 0 & $\$ 0$ & $\$ 483,840$ \\
\hline 2027 & 205 & $\$ 430,080$ & 0 & $\$ 0$ & $\$ 430,080$ \\
\hline 2028 & 179 & $\$ 376,320$ & 0 & $\$ 0$ & $\$ 376,320$ \\
\hline 2029 & 154 & $\$ 322,560$ & 0 & $\$ 0$ & $\$ 322,560$ \\
\hline 2030 & 128 & $\$ 268,800$ & 0 & $\$ 0$ & $\$ 268,800$ \\
\hline 2031 & 102 & $\$ 215,040$ & 0 & $\$ 0$ & $\$ 215,040$ \\
\hline 2032 & 77 & $\$ 161,280$ & 0 & $\$ 0$ & $\$ 161,280$ \\
\hline 2033 & 51 & $\$ 107,520$ & 0 & $\$ 0$ & $\$ 107,520$ \\
\hline 2034 & 26 & $\$ 53,760$ & 0 & $\$ 0$ & $\$ 53,760$ \\
\hline 2035 or later & 0 & $\$ 0$ & 0 & $\$ 0$ & $\$ 0$ \\
\hline
\end{tabular}

${ }^{*}$ Foreign expenditures exclude tank cleaning, which would otherwise cost a total of $\$ 192,000$ for all 128 stations any given year. Tank cleaning is excluded because it would likely be provided domestically. 
Currently boats, motorcycles, and lawn equipment cannot use E15 or E25. Accommodations must be made to ensure these machines have continued access to E10 or E0. Since ethanol is blended at the terminal and can be trucked in compartments about the same size as a station's underground storage tank, the current refueling infrastructure should be able to provide E10 even after E15 or E25 is the standard, with no additional infrastructure costs upstream from the station. However, octane additives may be needed in lieu of ethanol if E15 and E25 are 87 octane and, therefore, the blendstock is less than the normal 83 octane. ${ }^{3}$ Many boats refuel at marinas that should be allowed to continue selling E10 or E0. Home supply stores and equipment rental companies could be allowed to sell E10 and E0 through inexpensive aboveground storage tanks. Motorcycles could be given permission to refuel at both home supply stores and marinas, as they are low volume.

\section{Costs of Equipping vehicles}

Jamaica currently has a vehicle stock of 580,994 vehicles, allocated by vehicle type in Table 14 . Nearly 539 thousand of these are currently running on E10. Since ethanol is chemically identical regardless of what country or feedstock it comes from, it is assumed that all vehicles currently running on E10 could all run on domestic E10 without any upgrades or expenditures.

Table 14. 2017 Jamaican Vehicle Stock by Model Type

\begin{tabular}{|c|c|c|c|c|}
\hline & $\begin{array}{c}\text { Percent of } \\
\text { Total Imports }\end{array}$ & $\begin{array}{l}\text { Number of } \\
\text { Vehicles }\end{array}$ & $\begin{array}{l}\text { Percent } \\
\text { Gasoline }\end{array}$ & $\begin{array}{c}\text { No. of Gasoline } \\
\text { Vehicles }\end{array}$ \\
\hline Car & $68.7 \%$ & 399,167 & $99.5 \%$ & 397,319 \\
\hline Sport Utility Vehicle & $9.1 \%$ & 52,979 & $83.6 \%$ & 44,264 \\
\hline Motorcycle & $7.0 \%$ & 40,645 & $100.0 \%$ & 40,635 \\
\hline Van & $5.9 \%$ & 34,054 & $73.7 \%$ & 25,091 \\
\hline Light-duty Truck & $5.7 \%$ & 33,257 & $89.1 \%$ & 29,644 \\
\hline Bus & $1.8 \%$ & 10,490 & $15.4 \%$ & 1,612 \\
\hline Medium-duty Truck & $1.0 \%$ & 6,006 & $3.6 \%$ & 219 \\
\hline Semi-truck & $0.5 \%$ & 3,008 & $1.4 \%$ & 41 \\
\hline Heavy-duty Truck & $0.2 \%$ & 1,388 & $3.0 \%$ & 41 \\
\hline Total Vehicle Count: & $100 \%$ & 580,994 & $100 \%$ & 538,864 \\
\hline
\end{tabular}

Source: Total vehicle count from Johnson et al.( 2019) allocated by import percentages from the Tax Administration of Jamaica (2017).

Likewise, E15 should not require upgrades or expenditures to be used by Jamaica's light-duty vehicles (LDVs). After extensive research, the U.S. Environmental Protection Agency concluded that any non-motorcycle LDV of the model year 2001 or later could use E15 without damage to the vehicle (Biofuels Digest 2011). In Jamaica, vehicles are retired at an average age of 14.8 years (Johnson et al. 2019). This means that as of January 1, 2020, the average vehicle is a model year 2005-well within the safe range. The bell curve of vehicle age is not known for Jamaica, but in 2020 a vehicle will need to be at least 20 years old to be incompatible with E15.

Depending on the implementation schedule, E15 can likely be utilized without having any major

${ }^{3} 87$ octane E15 and E25 is not the advised fuel, as substantial efficiency gains can be made if the fuels have a higher octane, and engines are optimized to this higher octane 
impact on vehicles. The government could give collectors' vehicles permission to refuel at the same locations as motorcycles and boats.

The cost of equipping vehicles to utilize E25 comes from two needs. First, vehicles need components that can withstand higher levels of ethanol without corroding or degrading. This "ethanol tolerance" costs about $\$ 100$ per vehicle. ${ }^{4}$ Second, vehicles need gasoline direct injection (GDI) and turbochargers so that they can fully benefit from the additional octane in E25 to improve vehicle efficiency. GDI and turbochargers together cost an average of $\$ 355$ to add to a car at the manufacturing site (Duleep 2011).

GDI and turbochargers are already being installed on vehicles at an increasing rate. As shown in Figure 7, 51\% of the LDVs being sold into the U.S. market have GDI and 31\% have turbochargers. When averaged, the combined vehicles with both of these components follow a linear trend very closely $(\mathrm{R} 2=0.9935)$ between 2008 and 2018 . This trend is then projected from 2019 until it reaches $100 \%$ of LDVs in 2032. However, since Jamaica's vehicles are an average of 3.6 years old when imported, the date where $100 \%$ of vehicle purchases have GDI and turbocharge is 2036 .

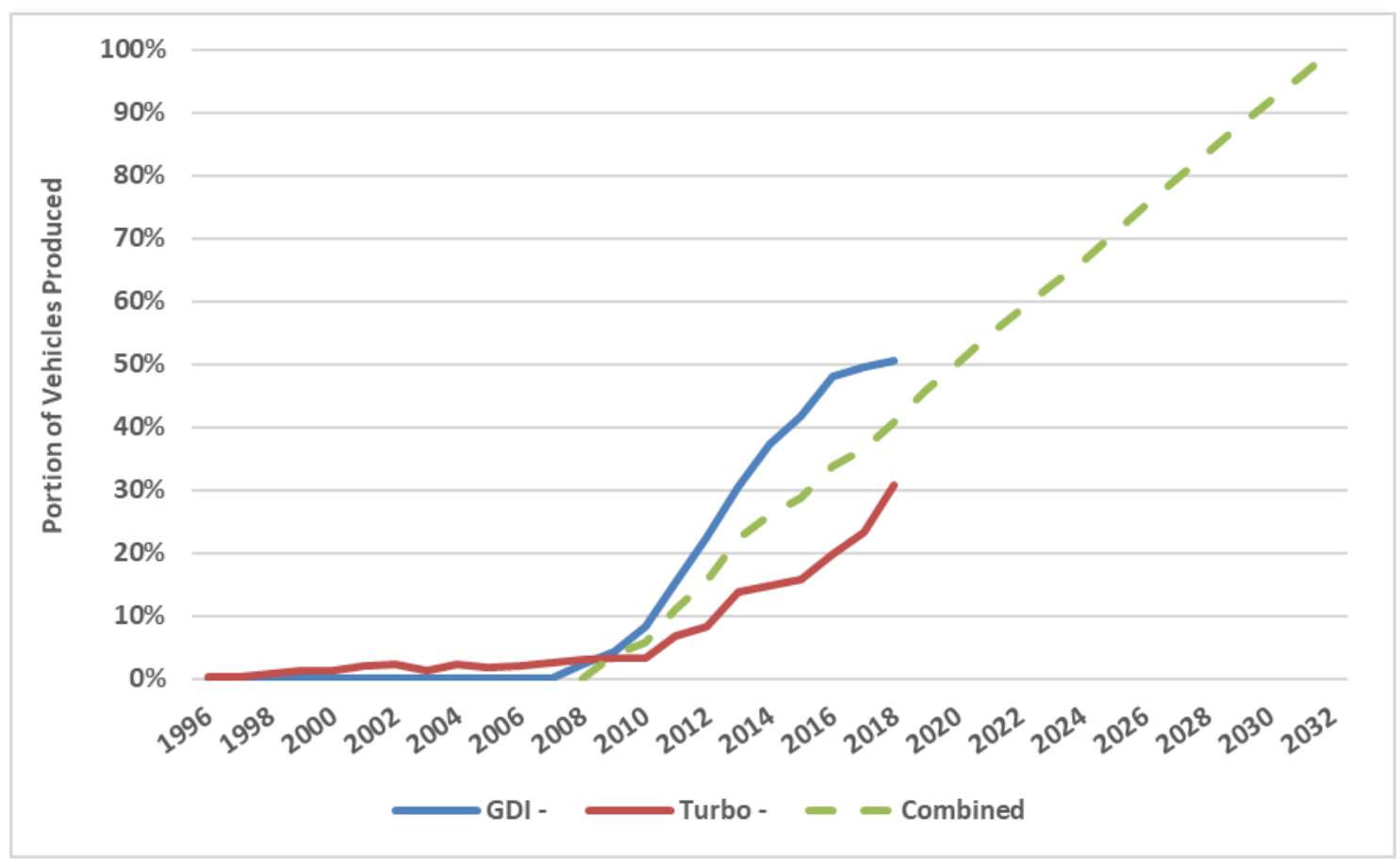

Figure 7. Penetration of GDI and turbo technologies into the U.S. LDV market

The incremental cost of E25-compatible vehicles is $\$ 455$ for the vehicles that would not have already had turbo and GDI, and it is $\$ 100$ (just the cost of ethanol tolerance) for the portion of vehicles that would have already had turbo and GDI installed, per the trends shown in Figure 7.

${ }^{4}$ A conservative estimate based on IBTimes (2010) and Congressional Record (2005) 
The incremental costs of purchasing E25-compatible vehicles instead of E10 vehicles are laid out in Table 15. Jamaica's annual import of gasoline vehicles is assumed to be 48 thousand in 2020 because the fleet of 539 thousand gasoline vehicles turns over every 11.2 years (539 thousand vehicles/11 years $=48$ thousand vehicles). Annual vehicle imports are expected to increase $1.1 \%$ per year, per projections laid out in Johnson et al. 2019. But an increasing portion of these vehicles would already have turbo and diesel and, therefore, forego the associated $\$ 355$ upgrade. This portion follows the green line in Figure 7, but lagged 4 years since the average vehicle imported to Jamaica is nearly 4 years old. The costs of turbo and GDI are, therefore, $\$ 355$ times the number of vehicles that would not already have these technologies. The cost of ethanol tolerance is the total number of gasoline imports times for that year times the $\$ 100$ incremental cost. The total cost is the sum of these two cost components.

Table 15. Cost of Purchasing E25 Vehicles instead of E10 Vehicles in Jamaica

\begin{tabular}{|c|c|c|c|c|c|}
\hline $\begin{array}{l}\text { Year E25 } \\
\text { Compatible }\end{array}$ & $\begin{array}{l}\text { Gasoline } \\
\text { Vehicle } \\
\text { Imports* }\end{array}$ & $\begin{array}{l}\text { \% of } \\
\text { Imports with } \\
\text { Turbo and } \\
\text { GDI }\end{array}$ & $\begin{array}{l}\text { Cost of Turbo } \\
\text { and GDI (\$M) }\end{array}$ & $\begin{array}{l}\text { Cost of } \\
\text { Ethanol } \\
\text { Tolerance } \\
\text { (\$M) }\end{array}$ & $\begin{array}{l}\text { Total Cost } \\
\text { (\$M) }\end{array}$ \\
\hline 2020 & 48,113 & $34 \%$ & $\$ 11.3$ & $\$ 4.8$ & $\$ 16.1$ \\
\hline 2021 & 48,642 & $37 \%$ & $\$ 11.0$ & $\$ 4.9$ & $\$ 15.8$ \\
\hline 2022 & 49,177 & $41 \%$ & $\$ 10.3$ & $\$ 4.9$ & $\$ 15.3$ \\
\hline 2023 & 49,718 & $46 \%$ & $\$ 9.6$ & $\$ 5.0$ & $\$ 14.5$ \\
\hline 2024 & 50,265 & $50 \%$ & $\$ 8.9$ & $\$ 5.0$ & $\$ 13.9$ \\
\hline 2025 & 50,818 & $55 \%$ & $\$ 8.2$ & $\$ 5.1$ & $\$ 13.3$ \\
\hline 2026 & 51,377 & $59 \%$ & $\$ 7.6$ & $\$ 5.1$ & $\$ 12.7$ \\
\hline 2027 & 51,942 & $63 \%$ & $\$ 6.9$ & $\$ 5.2$ & $\$ 12.1$ \\
\hline 2028 & 52,513 & $66 \%$ & $\$ 6.3$ & $\$ 5.3$ & $\$ 11.5$ \\
\hline 2029 & 53,091 & $71 \%$ & $\$ 5.5$ & $\$ 5.3$ & $\$ 10.8$ \\
\hline 2030 & 53,675 & $75 \%$ & $\$ 4.7$ & $\$ 5.4$ & $\$ 10.1$ \\
\hline 2031 & 54,266 & $79 \%$ & $\$ 4.0$ & $\$ 5.4$ & $\$ 9.4$ \\
\hline 2032 & 54,862 & $84 \%$ & $\$ 3.2$ & $\$ 5.5$ & $\$ 8.7$ \\
\hline 2033 & 55,466 & $88 \%$ & $\$ 2.4$ & $\$ 5.5$ & $\$ 8.0$ \\
\hline 2034 & 56,076 & $92 \%$ & $\$ 1.6$ & $\$ 5.6$ & $\$ 7.2$ \\
\hline 2035 & 56,693 & $96 \%$ & $\$ 0.8$ & $\$ 5.7$ & $\$ 6.5$ \\
\hline 2036 & 57,316 & $100 \%$ & $\$ 0.0$ & $\$ 5.7$ & $\$ 5.7$ \\
\hline 2037 onward & $1.1 \% / y r$. & $100 \%$ & $\$ 0.0$ & $1.7 \% / y r$. & $1.1 \% / y r .^{*}$ \\
\hline
\end{tabular}

*After increasing from 2037 (as explained below), the cost would be \$6.65 million in 2050.

Table 15 shows that the cost of E25 compatibility drops quickly as a larger portion of vehicles are produced with GDI and turbo. This cost is minimized at $\$ 5.7$ million in 2036, then it rises commensurately with the increase in vehicle imports (assumed 1.1\%/year). These costs could drop much more quickly if the pace of any of the required technologies is introduced to the global vehicle pool more quickly than expected. In particular, if vehicle manufacturers determine that the U.S. market is going the way of E15 and E25, they might start to make all of their vehicles E25-compatible. At that point, Jamaicans would be paying the additional $\$ 100$ for ethanol tolerance regardless of the ethanol level in Jamaica's gasoline. 


\section{Policy Support}

One of the most notable barriers to the production of biofuels in Jamaica is project financing. Without adequate funds needed to propel initiatives and keep them competitive, there is little ability to begin. Accordingly, many of the world's successful ethanol programs are bolstered by government subsidies and low-interest loans. During the 1970s, high oil prices in Brazil led to the encouragement of local fuel production, which in turn birthed Brazil's well-known National Alcohol Fuel Program (Pro-Alcool) in 1975. The program rolled out over two phases-first aiding in the expansion of existing capacity, and second in the construction of new capacity. Among several market advantages, ethanol investments procured low-interest loans, government purchasing quota, and favorable tax incentives (Szklo et al. 2005). However, in the early stages of Brazil's investment, the government justified its hands-on approach vis-à-vis the impact on local economies. In other words, though not immediately profitable, the positive externalities of ethanol production served as impetus for their efforts. The same could be true for Jamaica. With the assistance of multilateral development banks, such as the World Bank or the Inter-American Development Bank, Jamaica can craft a national subsidy and potentially secure concessional loans to complement the $\mathrm{CEF}$, revive the agricultural sector and produce domestic fuel at a price competitive with foreign ethanol. This can be done in pursuit of existing environmental and economic goals.

Sugarcane crop yields in Jamaica are currently not as good as neighboring countries, which makes the scenarios laid out in Table 5 more difficult to achieve and lessens the financial benefits laid out in the economic section. Therefore, training programs would need to be implemented whereby yield-improving technologies and techniques are transferred from highyield countries such as Brazil to Jamaican farmers.

Production incentives and programs must be paired with policies that enable and encourage the use of ethanol, thus creating a market for the producers. The first step was taken when Jamaica mandated that all gasoline contain 10\% ethanol, with an appropriate phase-in schedule. Similar mandates and phase-ins could be taken for E15 and E25. In addition, steps would need to be taken to reduce barriers to higher blends. Beginning as soon as possible, only E25-compatible fuel dispensers would be allowed for sale into the Jamaican market. This would ensure that as older E10 dispensers retire, they would be replaced with E25 dispensers and, therefore, fewer replacements would be needed at the time of the fuel mandate. Similarly, 90 octane vehicles would need to be encouraged so that the higher-octane E15 and E25 could be utilized efficiently, and the full value of higher-octane E15 and E25 could be monetized.

\section{Conclusions and Next Steps}

Jamaica has numerous options to produce its own ethanol to fulfill its E10 demand. Sugarcane is the most practical of these options, and each liter of domestically produced sugarcane ethanol that replaces imported corn ethanol would reduce GHG emissions by an estimated 29\% - 57\%. For higher blends, each liter of ethanol that replaces gasoline would reduce GHG emissions by nearly $80 \%$. This could result in $21-68$ thousand tonnes of GHG emissions reductions for E10, 122 - 169 thousand tonnes for E15, and 323 - 370 thousand tonnes for E25 by 2030. 
The potential exists for Jamaica to utilize land and equipment that were devoted to sugarcane production when the industry was much larger. However, further research is needed to determine the viability of utilizing existing infrastructure and what cost savings that could realize.

Jamaica has numerous scenarios that could be pursued toward domestic production of its fuel ethanol. Most involve a tradeoff of increasing the hectarage of sugarcane production (with a cap at the hectarage last seen in the 1960s) and increasing crop yield. More research is needed to investigate the most effective methods for increasing yields in a Jamaica-specific context.

General costs are addressed in this report, but further analysis is needed to determine options for funding the transition to domestic transportation fuel. In particular, the following should be considered for further investigation:

1. Economic impact analysis expanding analysis from a focus on the decrease in foreign expenditures to estimate increase in GDP (based on Jamaica's specific speed of money) and jobs

2. Technical capacity needs analysis, including farming yield improvements, fuel transport, and vehicle maintenance

3. Technical readiness of potential production facility sites

4. Production facility economic and technical feasibility assessments

5. Opportunity cost assessment with using sugar from the beverage industry for ethanol

6. Policy goals and incentives

7. Investor interest

8. Fuel testing protocols and standards/quality assurance

9. Scenario analysis of combining ethanol blends with other GHG-reducing technologies outlined in Johnson et al. 2019. These technologies reduce kilometers travelled and idle time, increase fuel economy, or utilize other alternative fuels such as electric vehicles.

10. Energy security benefits assessment of domestic ethanol at higher blends. 


\section{References}

All-Island Jamaica Cane Farmers’ Association. 2017. “Annual Report 2017.” September 2017.

All-Island Jamaica Cane Farmers' Association. 2018. "Regeneration...Annual Report 2018." September 2018.

All-Island Jamaica Cane Farmers' Association. 2019. Personal Communication.

Almeida, C. (2007). "Sugarcane ethanol: Brazil's biofuel success." June 2007.

https://www.scidev.net/global/policy/feature/sugarcane-ethanol-brazils-biofuel-success.html

Almodares, A. and Hadi, M.R. 2009. "Production of Bioethanol from Sweet Sorghum: A

Review." African Journal of Agricultural Research. Vol. 4 (9). pp. 772-780. September, 2009.

Andersen, V.F., Anderson, J.E., Wallington, T.J., Mueller, S.A., and Nielsen, O.J. 2010. "Vapor

Pressures of Alcohol-Gasoline Blends." Energy \& Fuels 24 (6): 3647-3654, doi:

$10.1021 /$ ef100254w.

Anderson, J., Wallington, T., Stein, R., and Studzinski, W. 2014. "Issues with T50 and T90 as Match Criteria for Ethanol-Gasoline Blends." SAE Int. J. Fuels Lubr. 7 (3): doi:10.4271/2014$01-9080$

Asia Pacific Economic Cooperation 2010. "Biofuel Costs, Technologies, and Economics in APEC Economies.” APEC Energy Working Group. December, 2010.

Auditor General's Department of Jamaica. 2019. "Auditor General's Department Special Audit Report: Ministry of Agriculture and Fisheries: Cane Expansion Fund.” Accessed June 2019. http://www.japarliament.gov.jm/attachments/article/1690/SIA\%20Special\%20Investigation\%20 \%20-\%20\%20June $\% 202016 . p d f$

Bandy, Betsy. 2019. Personal communication. May 2019. Ministry of Science, Energy, and Technology.

Barcelos, C., Maeda, R., Santa Anna, L.M., Pereira, Jr., N. 2016. "Sweet Sorghum as a WholeCrop Feedstock for Ethanol Production." Biomass and Bioenergy. Volume 94. November 2016. Pages 46-56.

Bezerra, T., and Ragauskas, A. 2016. "A Review of Sugarcane Bagasse for Second-Generation Bioethanol and n.” Biofuels, Bioproducts, and Biorefining. July 2016. https://doi.org/10.1002/bbb.1662

Bhatia, S.C. 2014. "Advanced Renewable Energy Systems." Chapter: 21.12.4 "SugarcaneMolasses-Ethanol Route.” 200 pages. Woodhead Publishing India.

Biofuels Digest. 2011. "EPA Approves E15 for Model Years 2001 and later, for Cars, SUVs, and Light Pickup Trucks.” January 24, 2011. 
Campbell, C. 2015. “Red Stripe Opens \$US2-M Cassava Processing Factory.” June. https://nationwideradiojm.com/red-stripe-opens-us2-m-cassava-processing-factory/

Campbell, E. 2017. "Fuel Plant Folly - Production Stopped at $\$ 800 \mathrm{~m}$ Ethanol Facility in Favour of Imports." The Gleaner. December 2017. http://jamaica-gleaner.com/article/leadstories/20171212/fuel-plant-folly-production-stopped-800m-ethanol-facility-favour

Caribbean Agricultural Research and Development Institute (CARDI). 2013. "Strengthening the Food Basket of the Caribbean Region: CARDI's Contribution to the Development of the Cassava Industry over the Past Three Decades." September 2013. http://www.cardi.org/wpcontent/uploads/downloads/2014/03/CARDI-contribution-to-development-Cassava-industryover-past-3-decades.pdf

Cheese Board. 2019. "Did you know that...." Accessed April 2019. http://www.cheeseboard.co.uk/facts/did you know that-1

Congressional Record. 2005. Senate Vol. 151, Pt. 19, p. 25766

Cortez, L., Leal, M., and Nogueira, L. 2019. "Sugarcane Bioenergy for Sustainable Development." Routledge.

Dairy Industries Jamaica Ltd. Accessed April 2019. http://dairyindustriesjamaica.com/

Davy, Lincoln. 2019. Personal communication June 2019. All-island Jamaican Cane Farmers Association.

Díez-Antolínez, R., Hijosa-Valsero, M., Paniagua-García, A., Garita-Cambronero, J., Gómez, X. 2018. "Yeast Screening and Cell Immobilization on Inert Supports for Ethanol Production from Cheese Whey Permeate with High Lactose Loads." in PLoS ONE. 13(12): e0210002. December 2018. https://doi.org/10.1371/journal.pone.0210002

Duleep, G. 2011. Comparison of Vehicle Efficiency Technology Attributes and Synergy Estimates (Subcontract Report). Golden, CO: National Renewable Energy Laboratory. NREL/SR-6A20-47806.

Ekefre, D., Mahapatra, A., Latimore Jr., M., Bellmer, D., Jena, U., Whitehead, G., and Williams, A. 2017. "Evaluation of Three Cultivars of Sweet Sorghum as Feedstocks for Ethanol Production in the Southeast United States." Heliyon. 3 (12). December 2017.

European Technology and Innovation Platform Bioenergy (ETIP Bioenergy). 2019. "Cellulosic Ethanol.” Accessed April 2019. http://www.etipbioenergy.eu/value-chains/products-enduse/products/cellulosic-ethanol

Food and Agriculture Organization of the United Nations (FAO). 2013. "Climate Change and Agriculture in Jamaica." September 2013. http://www.fao.org/3/a-i3417e.pdf.

Food and Agriculture Organization of the United Nations (FAO). 2019b. Beer Production Statistics for Jamaica. Accessed April 2019. http://www.fao.org/faostat/en/\#home. 
Food and Agriculture Organization of the United Nations (FAO). 2019c. Citrus Fruits Production Statistics for Jamaica. Accessed April 2019. http://www.fao.org/faostat/en/\#home.

Food and Agriculture Organization of the United Nations (FAO). 2019a. Crop Statistics for Jamaica. Accessed April 2019. http://www.fao.org/faostat/en/\#home.

Food Export. 2019. Food Export Association of the Midwest USA and Food Export USA Northeast. "Jamaica Country Profile." Accessed April 2019. https://www.foodexport.org/getstarted/country-market-profiles/caribbean/jamaica-country-profile

Global Agricultural Information Network 2018. “Jamaica Annual Sugar Report 2018.” April 2018.https://apps.fas.usda.gov/newgainapi/api/report/downloadreportbyfilename?filename=Suga r\%2Annual_Kingston_Jamaica_4-13-2018.pdf

González-García, S., Morales, P., and Gullón, B. 2018. "Estimating the Environmental Impacts of a Brewery Waste-Based Biorefinery: Bio-ethanol and Xylooligosaccharides Joint Production Case Study." Industrial Crops and Products Volume 123. November 2018. Pages 331-340.

Government of Jamaica. 2015. Intended Nationally Determined Contribution of Jamaica, Communicated to the UNFCCC. November 2015.

https://www4.unfecc.int/sites/ndestaging/PublishedDocuments/Jamaica\%20First/Jamaica's\%20I NDC_2015-11-25.pdf

Green Car Congress. 2015. "Ceres and Raízen sign Multi-Year Collaboration to Scale-Up Sweet Sorghum for Ethanol in Brazil." March 2015.

https://www.greencarcongress.com/2015/03/20150316-ceres.html

Green Social Bioethanol. 2019. “The Ethanol Micro Distillery.” Accessed April 2019. http://green-social.com/technology/

Hofstrand, D. 2009. "Brazil's Ethanol Industry.” April 2009. https://www.agmrc.org/renewableenergy/ethanol/brazils-ethanol-industry

IBTimes. 2010. “GM Seeking More U.S. Ethanol Fueling Stations.” Accessed October 27, 2019: www.ibtimes.com/gm-seeking-more-us-ethanol-fueling-stations-373411.

Intergovernmental Panel on Climate Change. 2006. IPCC Guidelines for National Greenhouse Gas Inventories. Prepared by the National Greenhouse Gas Inventories Programme. In:

Eggleston HS, Buendia L, Miwa K, Ngara T. Tanabe K, editors. Japan: IGES.

International Crops Research Institute for the Semi-Arid Tropics (ICRISAT). 2017. "Increasing Ethanol Production in India Using Sweet Sorghum.” May 2017.

https://www.icrisat.org/increasing-ethanol-production-in-india-using-sweet-sorghum/

Jalgaonkar, Shantanu. 2019. Personal Communication. Praj Industries Ltd. November 12, 2019.

Jamaica Information Service. 2014. "Cassava Processing Plant Under Construction in St.

Elizabeth.” April 2014. https://jis.gov.jm/cassava-processing-plant-construction-st-elizabeth/ 
Jamaica Information Service. 2015. "Petrojam Ethanol Company Limited." Accessed February 3, 2020 at https://jis.gov.jm/government/agencies/petrojam-ethanol-company-limited-pel/

Jamaica Observer. 2017. "Cheese please — Export Markets identified for Jamaican Products." August 2017. http://www.jamaicaobserver.com/business-report/cheese-please-8212-exportmarkets-identified-for-jamaican-products 107450 ?profile $=1442 \&$ template $=$ MobileArticle

Jamaica Promotions Corporation. (JAMPRO). 2016. "New Ethanol Plant for Jamaica." March 2016. http://www.jamaicatradeandinvest.org/news/new-ethanol-plant-jamaica.

Jamaica Star. 2019. "Bammy Factory wants more Cassava.” February 2019. http://jamaicastar.com/article/news/20190212/bammy-factory-wants-more-cassava

JN Foundation 2019. “Sugar Transformation Unit.” Accessed June 2019.

https://www.jnfoundation.com/partners/sugar-transformation-unit

Johnson, C., Koebrich, S., and Singer, M. 2019. Jamaica Transportation Greenhouse Gas Reduction Plan. NREL/TP-5400-73380. April 2019.

https://www.nrel.gov/docs/fy19osti/73380.pdf

Johnson, C., Newes, E., Brooker, A., McCormick, R., Peterson, S., Leiby, P., Uria Martinez, R, Oladosu, G., \& Brown, M. L. (2015). High-Octane Mid-Level Ethanol Blend Market Assessment. NREL/TP-5400-63698. December 2015. https://www.nrel.gov/docs/fy16osti/63698.pdf.

Kennedy, H. 2019. "GranBio to resume Ethanol Plant Commercial Operations.” Biofuels Digest. January 2019. https://www.biofuelsdigest.com/bdigest/2019/01/25/granbio-to-resume-ethanolplant-commercial-operations/

Klein, B., Chagas, M., Watanabe, M., Bonomi, A., and Filho, R. 2019. "Low Carbon Biofuels and the New Brazilian National Biofuel Policy (RenovaBio): A Case Study for Sugarcane Mills and Integrated Sugarcane-Microalgae Biorefineries." Renewable and Sustainable Energy Reviews. November 2019. https://www.sciencedirect.com/science/article/pii/S1364032119305738?via\%3Dihub

Koushki, M., Jafari, M., and Azizi, M. 2012. "Comparison of ethanol production from cheese whey permeate by two yeast strains." J. Food Sci. Technol. October 2012. 49 (5): 614-619.

Lavarack, B.P. 2003. "Estimates of Ethanol Production from Sugarcane Feedstocks.” Proc. Aust. Soc. Sugar Cane Technol., Vol. 25.

Leonard, D. 2018. “A Guide to The Jamaican Beer Scene.” January 2018. http://www.beersyndicate.com/blog/guide-jamaican-beer-scene/

Leone, T., Olin, E., Anderson, J., Jung, H., and Shelby, M., "Effects of Fuel Octane Rating and Ethanol Content on Knock, Fuel Economy, and $\mathrm{CO}_{2}$ for a Turbocharged DI Engine," SAE Int. J. Fuels Lubr. 7(1):9-28, 2014, https://doi.org/10.4271/2014-01-1228. 
Leone, Thomas G., Anderson, James E., Davis, Richard S., Iqbal, Asim, Reese II, Ronald A., Shelby, Michael H., and Studzinski, William M. 2015. "The Effect of Compression Ratio, Fuel Octane Rating, and Ethanol Content on Spark-Ignition Engine Efficiency," Environmental Science \& Technology 49 (18), 10778-10789, DOI: 10.1021/acs.est.5b01420

Li, M., Zhang, W., Hayes, D., Arthur, R., Yang, Y., and Wang, X. 2017. “China's New Nationwide E10 Ethanol Mandate and Its Global Implications." Agricultural Policy Review. Iowa State University. Fall 2017. https://www.card.iastate.edu/ag policy review/pdf/fall2017.pdf

Li, Yangrui and Wei, Yuan-An. 2006. "Sugar Industry in China : R \& D and Policy Initiatives to Meet Sugar and Biofuel Demand of Future." Sugar Tech 8(4): 203-216. December.

Ling, K.C. 2008. "Whey to Ethanol: A Biofuel Role for Dairy Cooperatives?.” February 2008. https://www.rd.usda.gov/files/RR214.pdf

Liu, H., Ren, L., Spiertz, H., Zhu, Y., and Hui Xie, G., 2014. "An Economic Analysis of Sweet Sorghum Cultivation for Ethanol Production in North China." Global Change Biology:

Bioenergy. August 2014. https://doi.org/10.1111/gcbb.12222

Loto, O. 2013. "Small Scale Ethanol Micro Distillery using Cassava and Cassava Peels as Feedstock." 2nd International Conference and Exhibition on Food Technology, Bioprocess \& Cell Culture. Kansas City, MO. J. Food Process. Technol. 2013, 4:10. October 2013. https://www.omicsonline.org/proceedings/small-scale-ethanol-micro-distillery-using-cassavaand-cassava-peels-as-feedstock-13130.html

Macedo, I.C., Seabra, J.E.A., and Silva, J.E.A.R. 2008. "Green House Gases Emissions in the Production and Use of Ethanol from Sugarcane in Brazil: The 2005/2006 Averages and a Prediction for 2020." Biomass and Bioenergy 32, 582-595.

Macrelli, S., Mogensen, J., and Zacchi, G. 2012. "Techno-economic Evaluation of 2nd Generation Bioethanol Production from Sugar Cane Bagasse and Leaves Integrated with the Sugar-Based Ethanol Process.” Biotechnol. Biofuels 5, 22. 2012. https://biotechnologyforbiofuels.biomedcentral.com/articles/10.1186/1754-6834-5-22

Mamma, D., and Christakopoulos, P. 2008. "Citrus Peels: An Excellent Raw Material for the Bioconversion into Value-Added Products." Tree and Forestry Science and Biotechnology 2. (Special Issue 1), 83-97. 2008.

Martinez, D., Feiden, A., Bariccatti, R., and Zara, R.K. 2018. "Ethanol Production from Waste of Cassava Processing." Appl. Sci. 2018. 8. 2158.

Mathias, T., Fernandes de Aguiar, P., Batista de Almeida e Silva, J., Moretzsohn de Mello, P., and Sérvulo, E. 2017. "Brewery Waste Reuse for Protease Production by Lactic Acid Fermentation." Food. Technol. Biotechnol. 2017 Jun; 55(2): 218-224.

McCormick, R. 2016. "High Octane Fuels: Benefits and Challenges." Presentation to Clean Cities Webinar. March 17, 2016. 
https://cleancities.energy.gov/files/u/news_events/document/document_url/158/CC_HOF_Webin ar_Combined.pdf

McCormick, R., Chupka, G., Christensen, E., Ratcliff, M., Burton, J., Alleman, T., Fouts, L., and Sindler, P. 2014. Increasing Biofuel Deployment and Utilization through Development of Renewable Super Premium. Milestone Completion Report. Golden, CO: National Renewable Energy Laboratory.

McKinsey. 2019. “Energy Insights: Global Downstream Outlook to 2035.” Accessed November 2020 at www.mckinsey.com/industries/oil-and-gas/ourinsights/ /media/64ECC6D805354081B82433E06258D375.ashx?

Medley, H. 2019. "High Molasses Imports Challenge Rum Industry." The Gleaner. February 2019. http://jamaica-gleaner.com/article/business/20190206/high-molasses-imports-challengerum-industry.

Merrick \& Company. 2019. "MillerCoors Ethanol Recovery Facility: Biomass Conversion to Ethanol." Accessed April 2019. https://www.merrick.com/project/millercoors-ethanol-recoveryfacility-biomass-conversion-ethanol/

Ministry of Agriculture \& Fisheries (MAF). 2014. "Report on the Achievements of the Sugar Transformation Unit (STU), Ministry of Agriculture and Fisheries." Ministry paper 59/2014. Accessed February 3, 2020 at https://japarliament.gov.jm/attachments/article/1276/1276_2014\%20MINISTRY\%20PAPER\%2 059.pdf

Ministry of Agriculture \& Fisheries (MAF). 2015. "Situation and Outlook Report On The Cassava Industry." February 2015. http://www.jamis.com/Companionsite/Repository Doc/Cassava\%20Research\%20Paper.pdf.

Ministry of Agriculture \& Fisheries (MAF). 2016. “Auditor General's Department Special Report: Ministry of Agriculture and Fisheries Cane Expansion Fund." Accessed February 3, 2020 at

www.japarliament.gov.jm/attachments/article/1690/SIA\%20Special\%20Investigation\%20\%20\%20\%20June $\% 202016 . p d f$

Ministry of Energy and Mining (MEM). 2010. "National Biofuels Policy 2010-2030." October 2010. https://www.mset.gov.jm/wp-content/uploads/2019/07/Draft-Biofuels-Policy_0.pdf

Ministry of Industry, Commerce, Agriculture and Fisheries (MICAF). 2018. "Closure of the Sugar Area Development Program/Sugar Transformation Project." Accessed February 2020 at https://micaf.gov.jm/content/closure-sugar-area-development-programmesugar-transformationproject

Ministry of Science, Energy, and Technology (MSET). 2019a. "Petroleum Consumption by Product." May 2019. https://www.mset.gov.jm/wp-content/uploads/2019/06/PETROLEUMCONSUMPTION-BY-PRODUCT-2018.pdf 
Ministry of Science, Energy, and Technology (MSET). 2019b. "Petrojam Ethanol Limited.” July 2019. https://www.mset.gov.jm/2019/07/02/petrojam-ethanol-limited/

Ministry of Science, Energy, and Technology (MSET). 2019c. Petroleum Imports. June 2019. https://www.mset.gov.jm/documents/petroleum-imports/

Ministry Paper. 2016. “Annual Report of the All-Island Jamaica Cane Farmers' Association for the Year Ended September 30, 2016.” September 2016. https://japarliament.gov.jm/attachments/article/2076/2019\%20Ministry\%20Paper\%208.pdf

Mithra, M., Jeeva, M., Sajeev, M., and Padmajaa, G. 2018. "Comparison of Ethanol Yield from Pretreated Lignocellulo-Starch Biomass under Fed-Batch SHF or SSF Modes.” Heliyon. 4(10): e00885.

Moriarty, Kristi, Kass, M., and Theiss, T. Increasing Biofuel Deployment and Utilization through Development of Renewable Super Premium: Infrastructure Assessment. No. NREL/TP5400-61684. National Renewable Energy Lab.(NREL), Golden, CO (United States), 2014.

Moriarty, Kristi. 2019. Personal Communication, May 15, 2019.

Mussatto, S., Dragone, G., and Roberto, I. 2006. "Brewers' Spent Grain: Generation, Characteristics and Potential Applications." Journal of Cereal Science. Volume 43. Issue 1. January 2006. Pages 1-14.

MyVueNews. 2015. "Red Stripe Starts Using Cassava.” June 2015. http://www.myvuenews.com/red-stripe-starts-using-cassava/

Navarro, X. (2008). “Makin' Ethanol from Cheese Factory Whey.” April 2008. https://www.autoblog.com/2008/04/21/makin-ethanol-from-cheese-factory-whey/

Negley, Scott. Personal Communication. May 14, 2019. Dover Fueling Solutions.

Ogbonna, J. C., Ndubuisi I. A., Murata, Y., and Omae, H. 2018. "Production of Ethanol from Cassava Processing Wastes in Nigeria." Presentation at IRENA's International Workshop: Sustainable Rural Bioenergy Solutions in Africa. January. https://www.irena.org/events/2018/Jan/Workshop-on-Sustainable-Rural-Biofuel-Strategy-inAfrica.

Oil Price Information Service and MathPro. 2017. The New Economics of Octane.

Organization of American States (OAS) and Winrock International. 2011. "Assistance for Biofuels Development and Policy Support in Jamaica." May.

http://www.oas.org/en/sedi/dsd/generaldocs/publications/jamaica_biofuels_report_final.pdf

Organization of American States. 2015. "Social Lifecycle Assessment and GBEP Indications of Biofuels in Jamaica." August. 
Patterson, C. 2016. "Four Companies Come Together to Revive Dairy Industry." March 2016. https://jis.gov.jm/four-companies-come-together-revive-dairy-industry/

Petersen, Abdul M., Van der Westhuizen, Willem A., Mandegari, Mohsen A., and Görgens, Johann F. 2018. "Economic Analysis of Bioethanol and Electricity Production from Sugarcane in South Africa." Biofuels, Bioproducts and Biorefining 12 (2): 224-238.

Petrojam Ethanol Limited. 2009. "Overview of Ethanol Production in Jamaica." Accessed June 2019. https://ran-s3.s3.amazonaws.com/petrojam.com/s3fspublic/resources/ethanol production_in jamaica.pdf

Petrojam Ethanol Limited. 2019. Personal communication with Petrojam representative. September 2019.

Potopsignh, R. 2016. “Report on Potential Ethanol Feedstocks - Jamaica.” May 2016. [link? Or more info?]

Pourbafrani, M., Forgács, G., Horváth, IS., Niklasson, C., and Taherzadeh, M.J. 2010.

"Production of Biofuels, Limonene and Pectin from Citrus Wastes." Bioresour. Technol. June. 101(11):4246-50.

ProBrewer. 2009. "Ethanol from Yeast.” February 2009. https://www.probrewer.com/ethanolfrom-yeast-538/

Sapp, M. 2019. "Nigeria to Begin Ethanol Production from Sweet Sorghum by the End of Q1." Biofuels Digest. January 2019. https://www.biofuelsdigest.com/bdigest/2019/01/14/nigeria-tobegin-ethanol-production-from-sweet-sorghum-by-the-end-of-q1/

Sims, B. 2007. “Converting Food \& Beverage Waste To Fuel.” June 2007.

http://ethanolproducer.com/articles/3094/converting-food-\&-beverage-waste-to-fuel

Sims, B. 2008. "Making Due with Waste Brew.” January 2008.

http://ethanolproducer.com/articles/3612/

Splitter, D., and Szybist, J. 2014a. "Intermediate Alcohol-Gasoline Blends, Fuels for Enabling Increased Engine Efficiency and Powertrain Possibilities.” SAE Int. J. Fuels Lubr. 7(1):2014, doi:10.4271/2014-01-1231

Splitter, D.A., and Szybist, J.P. 2014b. "Experimental Investigation of Spark-Ignited Combustion with High Octane Biofuels and EGR. 2. Fuel and EGR Effects on Knock-Limited Load and Speed.” Energy \& Fuels 28(2): 1432-1445, 2014, doi:10.1021/ef401575e

Sriroth, K., Wanlapatit, S. and Piyachomkwan, K. 2012. "Cassava Bioethanol.” Bioethanol. Prof. Marco Aurelio Pinheiro Lima (Ed.). IntechOpen, DOI: 10.5772/23112. February. http://www.intechopen.com/books/bioethanol/-cassava-bioethanol 
St1. 2018. "St1's Pilot to Produce Advanced Ethanol from Cassava Waste starts in Thailand." March 2018. https://www.st1.eu/st1s-pilot-to-produce-advanced-ethanol-from-cassava-wastestarts-in-thailand

Sugar Industry Authority (SIA). 2010. "The State of the Jamaican Sugar Industry." November 2010. https://www.jamaicasugar.org/files/SUGINDISO1110_nef4zl18.pdf

Sugar Industry Authority (SIA). 2017. "Cane and Sugar Production in Jamaica: 1975-2017." http://www.jamaicasugar.org/sugar-cane-production.html

Sugar Industry Authority (SIA). 2018. "SIA Annual Report 2017.” https://www.jamaicasugar.org/sia-annual-reports.html.

Sugar Industry Authority. (SIA). 2019a. "Cane and Sugar Production in Jamaica: 1975 - 2017." Accessed April 2019. https://www.jamaicasugar.org/sugar-cane-production.html.

Sugar Industry Authority (SIA). 2019b. "Bagasse Production in Jamaica during 2017/2018 Crop Year.” Personal Communication with Uriel Green, Team Leader, Research Projects Branch. Sugar Industry Authority Research Division.

Szklo, Alexandre Salem, Schaeffer, Roberto, Schuller, Marcio Edgar, and Chandler, William. 2005. "Brazilian Energy Policies Side-Effects on $\mathrm{CO}_{2}$ Emissions Reduction." Energy Policy 33, (3): 349-364.

Szybist, J., and West, B. 2013. "The Impact of Low Octane Hydrocarbon Blending Streams on the Knock Limit of 'E85', SAE Int. J. Fuels Lubr. 6(1):44-54, https://doi.org/10.4271/2013-010888 .

Szybist, J., Foster, M., Moore, W., Confer, K., Youngquist, A., and Wagner, R. "Investigation of Knock Limited Compression Ratio of Ethanol Gasoline Blends," SAE Technical Paper 2010-010619, 2010, doi:10.4271/2010-01-0619.

Tao, L., and Aden, A. 2009. "The Economics of Current and Future Biofuels." In Vitro Cellular \& Developmental Biology - Plant. 45:199-217. June.

https://www.researchgate.net/publication/226682226 The economics of current and future bi ofuels_In_Vitro_Cell_Dev_Biology_Plant

Thame, C. 2016. "New Ethanol Plant For Jamaica." The Gleaner. March 2016. http://jamaicagleaner.com/article/business/20160309/new-ethanol-plant-jamaica

The Gleaner. 2016. "Lessons On Cassava Flour.” August 2016. http://jamaicagleaner.com/article/letters/20160806/lessons-cassava-flour

The Heineken Company. 2019. "Project Grow." Accessed April 2019. https://www.theheinekencompany.com/sustainability/case-studies/project-grow 
Titus, M. 2017. "Local Entity Makes Play for Monymusk Sugar Factory.” The Gleaner. December. http://jamaica-gleaner.com/article/lead-stories/20171212/local-entity-makes-playmonymusk-sugar-factory

U.S. Department of Agriculture. 2006b. "Ethanol Feedstock From Citrus Peel Waste.” Ag Research Magazine. https://agresearchmag.ars.usda.gov/2006/apr/citrus

U.S. Department of Agriculture FAS. 2018b. "China Biofuels Annual 2018." November 2018. https://gain.fas.usda.gov/Recent\%20GAIN\%20Publications/Biofuels\%20Annual_Beijing_China \%20-\%20Peoples\%20Republic\%20of 7-25-2018.pdf

U.S. Department of Agriculture Foreign Agricultural Services. 2018a. "Jamaica Annual Sugar Report 2018."

https://gain.fas.usda.gov/Recent\%20GAIN\%20Publications/Sugar\%20Annual Kingston Jamaic a 4-13-2018.pdf

U.S. Department of Agriculture. 2006a. "The Economic Feasibility of Ethanol Production from Sugar in the United States.” July 2006.

https://www.usda.gov/oce/reports/energy/EthanolSugarFeasibilityReport3.pdf

U.S. Department of Agriculture. 2014. FAS. “China Biofuels Annual 2014.” November 2014. https://gain.fas.usda.gov/Recent\%20GAIN\%20Publications/Biofuels\%20Annual_Beijing_China \%20-\%20Peoples\%20Republic\%20of 11-4-2014.pdf

U.S. Department of Energy. 2016. Handbookfor Handling, Storing, and Dispensing E85 and Other Ethanol-Gasoline Blends. DOE/GO-102013-4854.

https://afdc.energy.gov/files/u/publication/ethanol handbook.pdf

U.S. Energy Information Administration (EIA). 2019a. EIA Petroleum Navigator. U.S. Exports to Jamaica of Fuel Ethanol. Accessed November 2019 at https://www.eia.gov/dnav/pet/hist/LeafHandler.ashx?n=pet\&s=m_epooxe_eex_nusnjm mbbl\&f=a

U.S. Energy Information Administration (EIA). 2019b. Annual Energy Outlook 2019. https://www.eia.gov/outlooks/aeo/tables ref.php

U.S. Energy Information Administration (EIA). 2019c. EIA Petroleum Navigator. U.S. Gulf Coast Conventional Gasoline Regular Spot Price FOB. Accessed November 2019 at https://www.eia.gov/dnav/pet/hist/LeafHandler.ashx?n=PET\&s=EER_EPMRU_PF4_RGC_DPG $\underline{\mathrm{ff}=\mathrm{A}}$

University of Kentucky College of Agriculture. 2013. "Sweet Sorghum for Biofuel." April. http://www.uky.edu/ccd/sites/www.uky.edu.ccd/files/sorghumbiofuel.pdf

Wang, Michael, Elgowainy, A., Benavides, P., Burnham, A., Cai, H., Dai, Q., Hawkins, T., Kelly, J., Kwon, H., Lee, D., Lee, U., Lu, Z., and Ou, L. 2018. Summary of Expansions and Updates in GREET® 2018. Argonne National Laboratory. https://greet.es.anl.gov/publicationgreet-2018-summary 
Wang, Michael, Han, Jeongwoo, Dunn, Jennifer B., Cai, Hao, and Elgowainy, Amgad. 2012. "Well-to-Wheels Energy Use and Greenhouse Gas Emissions of Ethanol from Corn, Sugarcane and Cellulosic Biomass for U.S. Use.” Environmental Research Letters 7(4): 045905.

West, Brian H. 2017. "High Octane Fuels, Making Better use of Ethanol. EESI High-Octane Fuels Briefing." November 13, 2017. www.eesi.org/files/Brian_West 111317.pdf

West, Brian H., Huff, Shean P., Moore, Larry G., DeBusk, Melanie Moses, and Sluder, Scott. 2018. Effects Of High-Octane E25 On Two Vehicles Equipped With Turbocharged, Direct-Injection Engines. ORNL/TM-2018/814. Oak Ridge National Lab.(ORNL), Oak Ridge, TN (United States).

Yang, Jiacheng, Roth, Patrick, Zhu, Hanwei , Durbin, Thomas D., and Karavalakis, Georgios. 2019. "Impacts of Gasoline Aromatic and Ethanol Levels on the Emissions from GDI Vehicles: Part 2. Influence on Particulate Matter, Black Carbon, and Nanoparticle Emissions." Fuel 252: 812-820.

Yang, X., Li, M., Liu, H., Ren, L., and Xie, G. 2018. "Technical Feasibility and Comprehensive Sustainability Assessment of Sweet Sorghum for Bioethanol Production in China." Sustainability 10, no. 3 (2018): 731.

Yu, J., Li, F., Lin, H., and Li, B. 2014. "Biofuels Development at COFCO: Past, Present, and Future.” Industrial Biotechnology. Vol. 10, No. 4. August 2014.

https://doi.org/10.1089/ind.2014.1514

Zhou, W., Widmer, W., and Grohmann, K. 2007. "Economic Analysis of Ethanol Production from Citrus Peel Waste.” Proc. Fla. State Hort. Soc.120:310-315. 